\title{
Article
}

\section{Central Counterparties and Liquidity Provision in Cash Markets}

\section{Thomas Richter}

check for

updates

Citation: Richter, Thomas. 2021. Central Counterparties and Liquidity Provision in Cash Markets. Journal of Risk and Financial Management 14: 584 https://doi.org/10.3390/jrfm14120584

Academic Editor: Thanasis Stengos

Received: 27 October 2021

Accepted: 29 November 2021

Published: 4 December 2021

Publisher's Note: MDPI stays neutral with regard to jurisdictional claims in published maps and institutional affiliations.

Copyright: (C) 2021 by the author. Licensee MDPI, Basel, Switzerland. This article is an open access article distributed under the terms and conditions of the Creative Commons Attribution (CC BY) license (https:// creativecommons.org/licenses/by/ $4.0 /)$.
ZHAW School of Management and Law, Technoparkstrasse 2, 8400 Winterthur, Switzerland; thomas.richter@zhaw.ch

\begin{abstract}
This paper investigates increased liquidity provision by market makers resulting from their ability to reduce balance sheet encumbrance through the use of central counterparties (CCPs). The introduction of the Basel III leverage rule constitutes a shock to market makers' balance sheets and thus affects their capacity to intermediate trades. Using trade-by-trade data from sovereign bond markets, we show that liquidity provision by CCP members decreased to a lesser extent following the rule change. We attribute these findings to balance sheet reductions due to the netting enabled by CCPs, thereby highlighting their importance in cash markets.
\end{abstract}

Keywords: trading activity; liquidity provision; market making; central counterparties; Basel III

JEL Classification: G10, G12, G18, G21

Balance sheet space is treated like expensive real estate, available only to positions that can afford to pay rental fees that are now much higher.

Darrell Duffie in Forbes, 11 March 2016

\section{Introduction}

Technology and new regulations are reshaping the market microstructure of fixed income markets. Recent research on the impact of technology on trading shows that electronic trading is growing and that markets have become more transparent $\left(\mathrm{O}^{\prime} \mathrm{Hara}\right.$ and Zhou (2021)). Moreover, since the financial crisis, new regulatory rules have reduced the capacity of traditional market makers to intermediate trades (see, e.g., Duffie (2017) or Di Maggio (2017)). Consistent with this, Fleming and Keane (2021) report that during the recent Covid-19-induced market stress episode, dealers' capacity to intermediate trades was not sufficient.

As a result of this, trading solutions that do not involve much risk or balance sheet space are in high demand. Duffie (2020) advocates the use of central counterparties and O'Hara and Zhou (2021) report that mechanisms that improve the matching between costumers and dealers such as requests for quotes play a very important role in the US corporate bond market.

Since the height of the European sovereign debt crisis, trading activity and liquidity in the European sovereign bond market have recovered only slowly.This observation is in line with evidence from the US Corporate Bond and Repo market and points to the negative impact of post-crisis regulation on the ability and willingness of financial intermediaries (Bessembinder et al. (2018); Adrian et al. (2017); Di Maggio (2017) and Duffie (2017)) to engage in market making. Di Maggio (2017) states: “The combination of post-crisis capital and liquidity regulations and a lower return environment has made banks less able and willing to function as market makers". In this context, we investigate CCP usage and trading activity around the introduction of the leverage rule back in 2013.

Duffie (2017) argued that the minimum leverage rule, phased in with Basel III, affects the market-making activities of banks in low-risk assets carried out with high leverage. The leverage rule is distinct from other elements of Basel III because it is applied to total 
assets (regardless of risk), while other capital requirements are applied to risk-weighted assets. Facing leverage constraints, banks terminate activities that contribute little to their profits but require high leverage (balance sheet space becomes more expensive).

Market making in sovereign bond markets is a prime example of such an activity. While not particularly risky, the intermediation of trades leads to the substantial expansion of the balance sheet of market makers who report under IFRS and use trade date accounting. A long balance sheet is costly because the Basel III exposure measure is derived (with a few exceptions) from accounting data and thus requires more regulatory capital. The interposition of a central counterparty (CCP) can mitigate this problem because it allows for the netting of positions and thus a reduction in balance sheet exposures.

On the basis of a difference-in-difference methodology, this paper studies the consequences of Basel III rules for the leverage ratio, enacted into European law on 26 July 2013, on trading activity and liquidity in the European Sovereign debt market. ${ }^{1}$ We exploit the fact that a trade executed via a CCP renders market making less balance-sheet-intensive. We assess the impact of the Basel III leverage rule on liquidity provision by comparing its differential impact on trades that are not executed over a CCP (treatment group) to those that are (control group). European sovereign bonds are a suitable setting to study this topic because they have zero risk weights and are thus (unlike other assets) not affected by contemporaneous changes in the risk-based framework of Basel III.

We used data from MTS, the largest European electronic trading platform for sovereign bonds in the interdealer market (Dunne et al. (2010)). This data set has two distinct features that make it useful for studying the use of CCPs. First, the data set contains information about whether a trade was executed with the interposition of CCPs. Second, it is voluntary for MTS dealers to be a member of a CCP, which means that there is variation in CCP usage. A trade is executed via the CCP if both market participants are members of the CCP and certain eligibility criteria are satisfied.

We expect a greater decrease in liquidity provision by non-CCP market makers and thus a greater decrease in trading activity that is not routed via CCPs compared to trading activity involving CCP usage. This occurs via two mechanisms. First, CCP members have an increased willingness to execute trades that have a high likelihood of being executed over a CCP. Second, a higher number of dealers on MTS are members of a CCP. Consistent with this hypothesis, descriptive statistics reveal that the average volume of trades (for the average bond) not executed via a CCP dropped by 11.2\%, from EUR 31.57 million to EUR 28.42 million, after Basel III was introduced into European law. In contrast, the volume of CCP trades increased from EUR 36.91 million to EUR 54.31 million (47.1\%). These results are also confirmed in a more elaborate difference-in-difference regression setting that accounts for differences between the two groups, time fixed effects, bond fixed effects, and an extensive set of control variables.

Similarly, we expect dealers to post narrower bid-ask spreads for securities where a resulting trade has a higher likelihood of being executed via a CCP. In line with this intuition, the difference-in-difference regressions reveal that the increase in bid-ask spreads is 3.4 bps higher for bonds with a low likelihood of being traded via CCPs.

Using a placebo test, we confirm that our results are not driven by an increasing trend of CCP usage that is unrelated to the introduction of Basel III. In addition, our results have been proven to be robust to the functional form and the inclusion of zero-trading days. Additionally, we show that the differences between the two groups are more pronounced at the end of the quarter (window dressing) and that they hold for different country groups.

We contribute to the literature that explores the effects of CCPs on financial markets by studying their balance sheet effects as opposed to effects arising from a reduction in counterparty risk or anonymity (Cont and Kokholm (2014); Loon and Zhong (2014); Mancini et al. (2015); and Bellia et al. (2018)). Moreover, we study cash markets as opposed to derivative and repo markets. As a result, these findings help to explain the existence of CCPs in cash markets. Traditional counterparty risk explanations for CCP usage cannot explain their 
existence in cash markets because the delivery-versus-payment settlement infrastructure (DVP) eliminates counterparty risk (except for pre-settlement risk reduction). ${ }^{2,3}$

Furthermore, we contribute to the literature that studies the impact of capital regulation on market making. Adrian et al. (2017) and Bao et al. (2016) studied the relation between capital regulation and market-making activities and found that the capacity of banks to make markets seems to have been impaired by recent regulatory reforms such as Basel III and the Volcker Rule. We contribute to this literature by showing how market makers can use CCPs to mitigate the adverse effects of regulation and how netting benefits arising from CCP usage has become more valuable when balance sheet space becomes more expensive.

In addition, this paper isolates the effect of the leverage rule from changes in the risk-weighted capital regulation associated with Basel III because European banks can apply zero risk weights to European sovereign exposures in euros. In a broader context, we also add to the strand of research that links a dealer's wealth (reflected in his balance sheet) to liquidity provision (Ho and Stoll (1981); Bessembinder et al. (2018); Comerton-Forde et al. (2010).

By the virtue of studying CCPs on the MTS platform, we are related to papers that study the market microstructure of this platform. Dufour et al. (2019) study the intraday dynamics and the selection of collateral in centrally cleared and bilateral repos. Using MTS data as well as data from ICAP BrokerTec, Boissel et al. (2017) study the probability of CCP defaults in times of stress. Both papers focus on repo markets, while this paper focusses on cash markets.

The rest of this paper is organized as follows. Section 2 discusses the institutional details of CCP usage on the MTS platform, and the balance sheet effects of CCPs and Basel III. Section 3 presents the data. Section 4 defines the variables and shows descriptive statistics. Section 5 contains the main empirical analysis, and Section 6 presents robustness checks. Section 7 concludes the paper.

\section{Institutional Background}

\subsection{Basel III Leverage Rule and Market Making}

The 2007-2008 financial crises showed that banks were able to maintain high leverage ratios while still complying with the risk-based capital ratios set by regulators (BCBS (2014)). However, the crisis initiated a process that led to a spiral of deleveraging, losses and falling bank capital, resulting in a severe financial crisis (BCBS (2014); Mendoza (2010); and Brunnermeier (2009)). Academics further pointed out problems with the banks' discretion in determining the risk weights of exposures (Blum (2008)).

To overcome these shortcomings, Basel III introduced a non-risk-based leverage ratio in addition to risk-based capital requirements. The Basel III leverage ratio is defined as bank capital divided by bank exposure. BCBS (2014) specifies that bank capital is the Tier 1 capital (core capital) of the risk-based capital framework. The exposure measure is generally based on accounting values of positions and should cover on-balance sheet derivatives, securities financing transactions and off-balance sheet exposures. ${ }^{4}$

The first consultative documents for the new Basel III framework (including a proposal for the leverage rule) were issued in December 2009 and were amended and revised over the following years. ${ }^{5}$ The Basel III rules were introduced in the European Union with the Capital Requirements Directive IV (EU) No 575/2013 on 26 June 2013. The directive came into effect on 1 January 2014 (with the exception of some particular articles). On the same date, the BCBS published a consultative document proposing changes to the exposure measure (see BCBS (2013); Smith et al. (2017)), which was published in a finalized version on 12 January $2014 .^{6}$

The leverage rule was not immediately a binding Pillar 1 requirement. The BCBS first defined a test period with a minimum Tier 1 leverage ratio of $3 \%$ during the period from 1 January 2013 to 1 January 2017 to collect data and determine potential refinements. Banks were required to report their leverage ratios to their respective national supervision 
authority as of 2013 and to the public as of 2015 (Pillar 3-CRR Art. 430). Additionally, the leverage ratio was made part of the supervisory review process of banks (Pillar 2-CRD IV Art. 87). In the course of 2017, the BCBS finalized the necessary rules (see BCBS (2017b)), and in 2018, the leverage ratio became a binding capital requirement (Pillar 1) for banks (CRR L 176/12 (93)).

Duffie (2017) argued that the leverage rule forces dealers to hold more equity for non-risky activities (e.g., market making in sovereign bonds). The dealer's creditors profit from this while shareholders lose (wealth transfer). In line with his arguments, dealers are only interested in offering market-making services if the rental fee for space on the balance sheet is at least as high as the wealth transfer. Thus, one can conclude that either the leverage ratio makes trading more expensive or market makers stop providing marketmaking services. Consistent with this, a BIS survey (Committee on the Global Financial System (2016)) among market makers showed that capital charges in 2015 amounted to approximately $40 \%$ of gross market-making revenues, which corresponds to a $24 \%$ increase compared to 2010. Many respondents stated that the leverage ratio was the main cause for the increase.

We argue that banks in the European sovereign bond markets started to adapt their market-making activities to the rule change due to the implementation of Basel III on 26 July 2013. This is confirmed by data at the bank level collected by the BCBS and reported in Basel III monitoring reports. Figure 1 plots the leverage ratio, the exposure and the Tier 1 capital ratio for group 1 banks (those that have Tier 1 capital of more than EUR 3 billion and are internationally active) and group 2 banks (all others). While these quantities were initially relatively stable, they began rising sharply in the second half of 2013. Interestingly, group 1 banks seem to have mainly increased Tier 1 capital, while group 2 banks also markedly reduced their exposure. This pattern is consistent with the assumption that banks changed their business models to comply with the leverage rule around the time that it was introduced to European law. This is also consistent with the assertions of market participants in the above-mentioned (Committee on the Global Financial System (2016)) survey (with 2015 data), which confirms that banks had already made adjustments to their business models by the time as if Basel III was fully phased in.
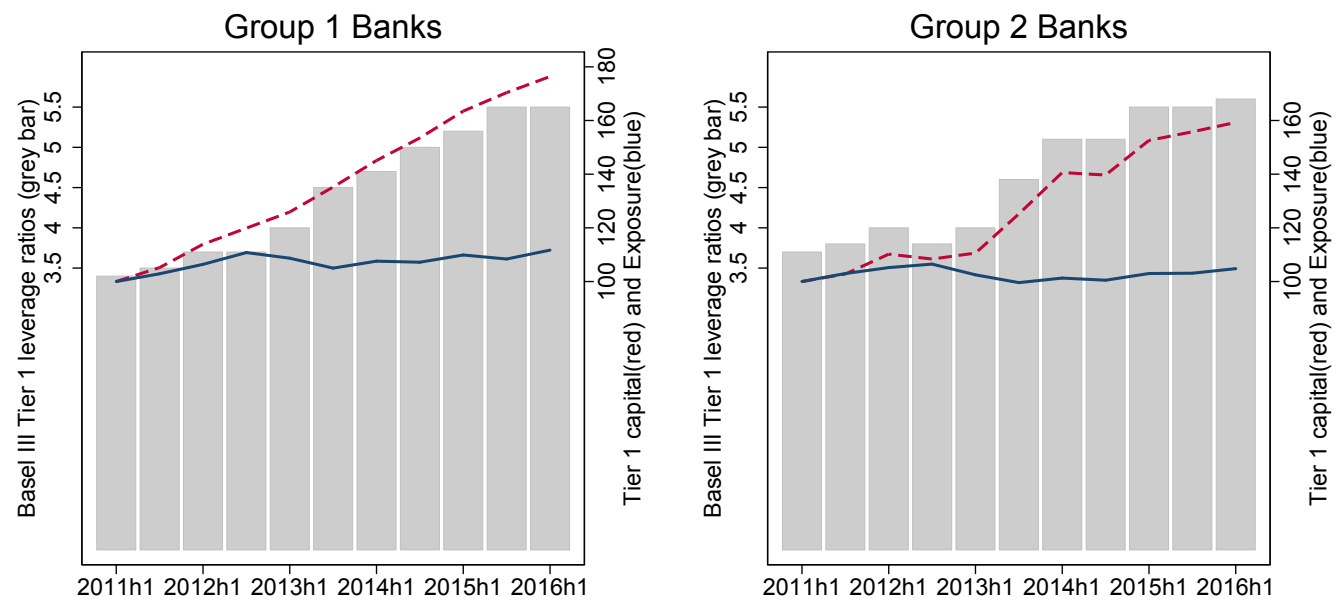

Figure 1. Basel III leverage ratio over time for group 1 and group 2 banks. This figure displays the Basel III Tier 1 leverage ratios (gray bars), Tier 1 capital (dashed red line) and the exposure measure. The Basel III leverage ratio is calculated by dividing Tier 1 capital by the exposure. The Tier 1 ratio and the exposure are calculated from accounting data and refinements, as defined in BCBS (2014). The figure shows these numbers for group 1 (banks that have Tier 1 capital of more than EUR 3 billion and are internationally active (BCBS (2017a))) and group 2 banks (all other banks) at a biannual frequency during the period from 2011 to 2016. The data are sourced from Table A.16 (p. 50) in BCBS (2017a). 


\subsection{Trading on the MTS Platform}

MTS is the largest electronic trading platform for European sovereign bonds in the interdealer market (Dunne et al. (2010)). Trading takes place on either a domestic platform or on a pan-European platform. The spectrum of market participants ranges from small regional banks to major financial institutions. In this paper, we focus on euro area sovereign bond markets with sufficient variation in CCP usage (Austria, Belgium, Germany, Ireland, Italy and Finland—see Section 3 for details about sample selection). Table 1 contains information and statistics about the trading activity and trading infrastructure in these markets.

For each bond, a number of dealers can post bid and ask prices (market makers), while other dealers (participants) can only enter market orders (Foucault et al. (2013)). The average number of market makers for a particular bond varies between 8.5 (Italian bonds) and 23.5 (Austrian bonds), while the number of participants ranges between 34.4 (The Netherlands) and 75.1 (Italy). The average yearly EUR trading volume (during our sample period from 2012 to 2014) in these markets ranges between 893.2 billion (corresponding to more than 53,660 trades) in the Italian market and 6.4 billion in the Irish market.

Table 1. Descriptive statistics of markets.

\begin{tabular}{|c|c|c|c|c|c|c|c|c|}
\hline & CCP & CSD & $\mathbf{P}$ & MM & Volume & $\%$ CCP & Trades & $\% \mathrm{CCP}$ \\
\hline$A T$ & LCH.Clearnet Ltd. & $\begin{array}{l}\text { Euroclear Bank } \\
\text { Clearstream Banking Luxemburg }\end{array}$ & 36.4 & 23.5 & 17,201 & $4.2 \%$ & 3223 & $10.6 \%$ \\
\hline$B E$ & LCH.Clearnet Ltd. & $\begin{array}{l}\text { National Bank of Belgium } \\
\text { (NBB-SSS) }\end{array}$ & 32.7 & 19.7 & 320,143 & $29.2 \%$ & 23,163 & $40.9 \%$ \\
\hline$D E$ & LCH.Clearnet Ltd. & $\begin{array}{l}\text { Euroclear Bank Brussels } \\
\text { Clearstream Banking Luxembourg } \\
\text { and Frankfurt }\end{array}$ & 44.3 & 10.4 & 51,529 & $35.9 \%$ & 10,935 & $32.3 \%$ \\
\hline$F I$ & LCH.Clearnet Ltd. & $\begin{array}{l}\text { Euroclear Bank } \\
\text { Clearstream Banking Luxemburg }\end{array}$ & 32.8 & 22.1 & 46,784 & $18.9 \%$ & 5097 & $31.2 \%$ \\
\hline$I E$ & LCH.Clearnet Ltd. & $\begin{array}{l}\text { Euroclear Bank } \\
\text { Clearstream Banking Luxemburg }\end{array}$ & 27.4 & 19.2 & 6457 & $1.1 \%$ & 1451 & $3.7 \%$ \\
\hline IT & $\begin{array}{l}\text { LCH.Clearnet SA } \\
\text { CC\&G }\end{array}$ & Monte Titoli & 75.1 & 8.5 & 893,206 & $95.1 \%$ & 53,669 & $82.1 \%$ \\
\hline$N L$ & LCH.Clearnet Ltd. & $\begin{array}{l}\text { Euroclear Bank } \\
\text { Clearstream Banking Luxemburg }\end{array}$ & 34.4 & 21.9 & 174,330 & $30.4 \%$ & 17,420 & $40.3 \%$ \\
\hline
\end{tabular}

This table contains information about trading, settlement and CCPs in the studied markets: Austria (AT), Belgium (BE), Germany (DE), Finland (FI), Ireland (IE), Italy (IT) and The Netherlands (NL). The first two columns contain information collected from the MTS website. The first column identifies companies that provide CCP services in these markets. The second column contains information about the available settlement agents. The remaining columns contain summary statistics calculated from data for the January 2012-December 2014 period: the average number of market participants $(\mathrm{P})$, the average number of market makers for the average bond (MM), the average yearly EUR volume (volume in million), the percentage of EUR volume traded via CCPs (\% CCP), average number of trades in a year (Trades) and the percentage of trades that were routed via a CCP.

Table 2 contains information about the balance sheets of the MTS participants. The median MTS participant holds assets worth EUR 127 bn and Tier 1 capital of EUR 6.4 bn. The leverage ratio calculated from these two numbers ranges between $1.89 \%$ and $12.32 \%$, with a median of $5.07 \%$. This number is not consistent with the Basel III leverage ratio since (among other things) it does not contain the necessary adjustments and off-balance sheet exposures. The number is thus positively biased. However, even these numbers clearly show that the Basel III leverage ratio will be binding for some institutions. In addition, the balance sheet numbers show that positions from trading and, particularly, debt instruments held for trading make up a significant part of the balance sheets of financial institutions that are MTS members. 
Panel B of Table 2 compares balance sheet positions between 2012 (before Basel III) and 2014 (after Basel III). These data seem to suggest that the Basel III leverage ratio requirement has had a similar impact on MTS participants and the entire set of banks, as reported in the Basel III Monitoring report (see Section 2.1 and Figure 1). Banks decrease total assets and increase Tier 1 capital. Moreover, the numbers show substantial reductions in positions that can be financed with a high level of leverage, such as debt instruments.

For the countries in our sample and during our sample period (2012-2014), optional CCP services were provided by LCH.Clearnet Ltd. in the Austrian, Belgian, Dutch, Finnish, German and Irish markets and by LCH.Clearnet S.A. and the Cassa di Compensazione e Garanzia (CC\&G) in the Italian market (see also Table 1). ${ }^{7}$ Figure 2 shows that the share of CCP trades increased from $62 \%$ pre-Basel III to $73 \%$ after its introduction. The regional distribution also shows a huge variation in CCP usage among countries. In Italy, 95.1\% of the EUR volume or $82.1 \%$ of the trades are routed via CCPs, while only $3.7 \%$ of the trades in Ireland are executed with the involvement of a CCP (see Table 1).

Table 2. Descriptive statistics of MTS market makers.

\begin{tabular}{lccccc}
\hline Panel A: Descriptive Statistics MTS Market Makers & & & & \\
& Mean & p50 & sd & p5 & p95 \\
\hline Total Assets & 457.2 & 127.0 & 699.0 & 1.1 & 1910.0 \\
Leverage & $6.54 \%$ & $5.07 \%$ & $8.52 \%$ & $1.89 \%$ & $12.32 \%$ \\
Tier 1 Common Capital & 19.8 & 6.4 & 33.1 & 0.1 & 94.5 \\
Total Risk-Weighted Assets & 166.1 & 58.7 & 276.0 & 0.7 & 819.0 \\
Total Assets Held for Trading & 118.5 & 13.4 & 219.0 & 0.0 & 674.0 \\
Debt Instruments Held for Trading & 30.1 & 3.0 & 68.0 & 0.0 & 158.0 \\
\% Debt & $32.69 \%$ & $25.50 \%$ & $25.88 \%$ & $1.25 \%$ & $93.48 \%$ \\
Equity Instruments Held for Trading & 8.4 & 0.3 & 19.7 & 0.0 & 61.4 \\
\% Equity & $7.17 \%$ & $2.70 \%$ & $10.64 \%$ & $0.03 \%$ & $29.53 \%$ \\
\hline Panel B: Change in Balance Sheet Positions & \% Debt & \% Equity & TA & CET1 & Leverage \\
& -0.028 & $0.032 * *$ & $-15.0 * *$ & $1.337 * *$ & $0.003 *$ \\
\hline Difference 2014-2012 & $(-1.29)$ & $(2.62)$ & $(-2.42)$ & $(2.21)$ & $(1.99)$ \\
\hline
\end{tabular}

Panel A contains descriptive statistics about the balance sheet positions of MTS market makers. The data were retrieved from SNL Financial. We report the mean, median, standard deviation (sd) and 5\% and 95\% quantiles (p5 and p95) for each variable. The following variables were directly obtained from SNL (SNL Key in parentheses), are expressed in EUR billions and are yearly averages over the 2012-2014 time period: Total Assets (132,264), Tier 1 Common Capital (260,774), Total Risk-Weighted Assets (133,174), Total Assets Held for Trading (225,000), Debt Instruments Held for Trading $(224,995)$ and Equity Instruments Held for Trading $(224,996)$. A detailed description of how SNL calculated and collected these variables can be found in the SNL Data Wizard. From these numbers, we calculated Leverage as Tier 1 Common Capital divided by Total Assets. The variable \% Debt Instruments Held for Trading (\% Equity Held for Trading) was obtained by dividing Debt Instruments Held for Trading (Equity Instruments Held for Trading) by Total Assets. Panel B displays the average change in selected variables between 2012 and 2014. ** and * denote statistical significance at the 1\%,5\% and $10 \%$ levels, respectively.

In order to make use of a CCP, a dealer has to be a member of the CCP. To be eligible for a membership, firms must comply with minimum net capital requirements (e.g., EUR 100 million for LCH.Clearnet SA) and have the necessary banking arrangements, staff with sufficient knowledge and systems to manage clearing activities appropriately. ${ }^{8}$ Once a member, the CCP requires participants to post collateral that covers the current risk exposure that they incur for the CCP, which depends on the risk of the open position (Haene and Sturm (2009)). 

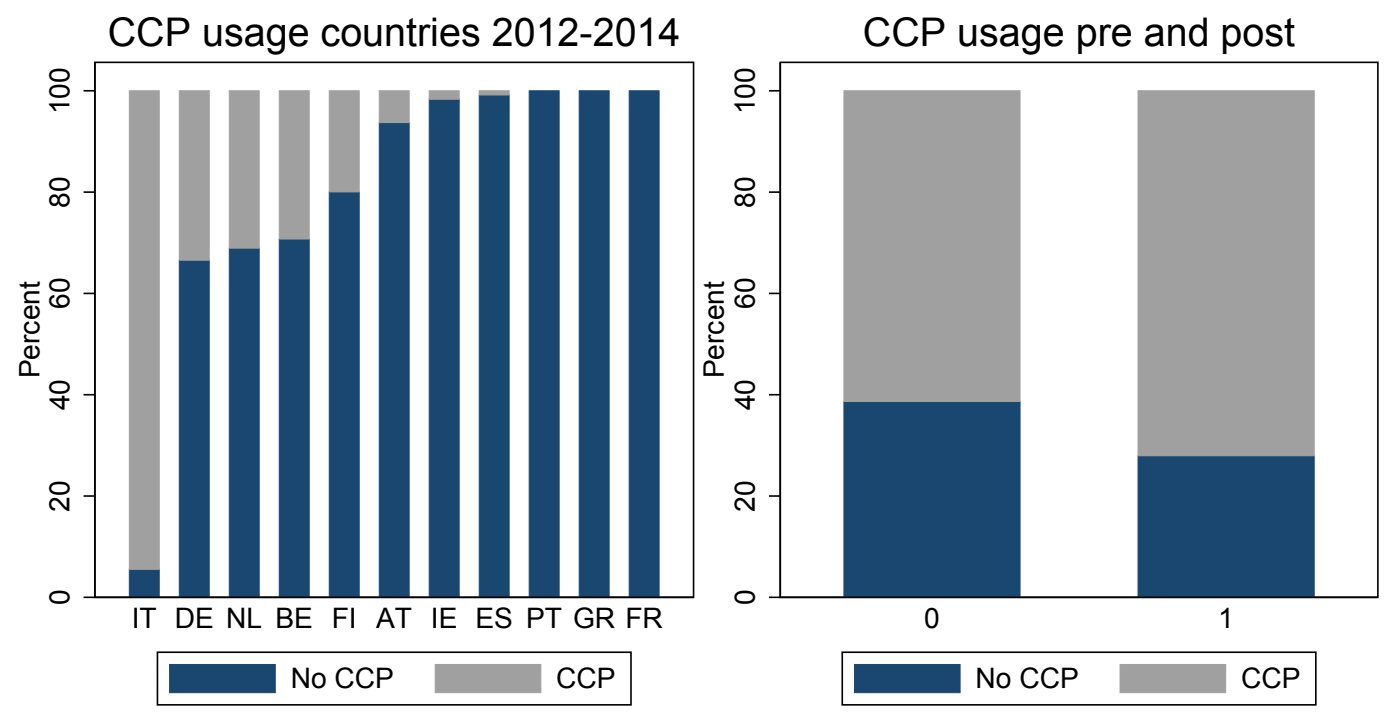

Figure 2. CCP usage across countries and over time. This figure displays the percentage share of trading activity that is executed in cooperation with a CCP (gray bars) and the share of trading activity that is not routed via a CCP (dark blue bars). The trading activity measure used to create the graph is trading volume in millions of euros. On the left, we display the aggregate shares over the entire sample period from 2012 to 2014 for different countries. On the right, we show the shares preand post-Basel III.

If two dealers agree on a trade and are both members of a CCP, MTS sends Swift trade messages on behalf of both participants to the CCP. ${ }^{9}$ Then, if the trade fulfills the eligibility criteria of the $\mathrm{CCP}$, the so-called novation takes place, where the CCP interposes itself between the two trading parties and thus enables the netting of positions. ${ }^{10}$ In the netting process, there is no distinction between the securities part of repo trades or bond trades from different platforms. ${ }^{11}$

The settlement system of a market and thus the use of a CCP service have important implications for settlement risk arising from trading. According to Bank for International Settlements (1992) settlement risk comprises counterparty credit risk and liquidity risk. Counterparty credit risk arises when a security is delivered (cash payment is made) and the counterparty does not deliver the cash (the security) because it is in default. Liquidity risk originates in situations where a trade fails because one party does not provide the securities or cash required to settle the trade. This leaves the opposite counterparty without the securities or cash needed to fulfill other obligations.

The current European security settlement infrastructure relies on delivery versus payment (DvP) systems (see CPMI (2015)). In DvP systems, securities and funds are exchanged between counterparties simultaneously, which prevents situations in which only one counterparty lives up to the legal requirements of the trade. In other words, counterparty credit risk is eliminated through the use of these settlement mechanisms. Market participants are, however, still exposed to liquidity risk. However, the magnitude of this risk is rather small since settlement failures are rare and replacing trades is easy (the market is liquid) and inexpensive (sovereign bonds usually only experience moderate price changes). Thus, counterparty risk seems to play a less important role compared to previously studied markets, such as repo and derivative markets.

\subsection{Balance Sheet Effects of Central Counterparties}

In this paper, we argue that the frequent use of CCPs in a cash market is at least partially attributable to their balance sheet effects. The effects discussed in this section are based on the regulatory rules in place during our sample period (2012-2014). ${ }^{12}$ In sovereign bond markets, the balance sheet effects of CCPs originate from the interplay between IFRS 
banks using trade date accounting and the fact that the Basel III leverage ratio regulation relies on an exposure measure that is generally derived from accounting data. ${ }^{13}$

When a bank complies with IFRS and applies trade date accounting (IAS 39.AG55), a bond purchase is recorded in the balance sheet by the recognition of an asset and a corresponding liability towards the seller of the security (due on the settlement date) on the trade date. Similarly, a sale will be accounted for by the de-recognition of the asset against a receivable towards the buyer of the security. ${ }^{14}$ If no CCP is used and a market maker is buying from one counterparty and selling to another, he cannot offset the liabilities and receivables arising from these two trades because the netting is not legally enforceable (IAS 32.42). However, if the trades are handled with the involvement of a CCP, the market maker can apply the offsetting rules because he has only a small (legally enforceable) net position towards the CCP.

This implies that trading via a CCP and bilateral trading are affected differently by the leverage rule. In this paper, we exploit this to identify the effect of the leverage rule on trading activity and liquidity in the European sovereign bond market. This issue does not apply to US broker-dealers because they are allowed to offset liabilities and trades (AICPA (2017)) However, $79.78 \%$ of the MTS participants report in accordance with IFRS accounting rules (see Figure 3). The issue does not arise for banks that use settlement date accounting. ${ }^{15}$ However, again, $64.71 \%$ of the MTS market-making activities are supported by dealers who report using trade date accounting.

Trade vs. Settlement Date Accounting
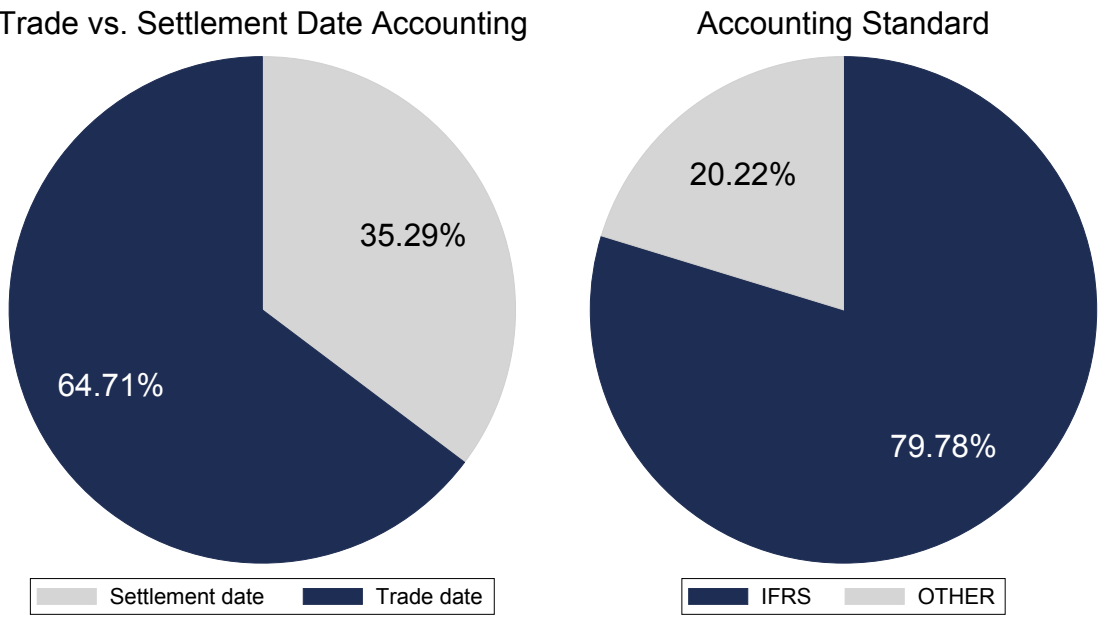

Figure 3. Accounting standards and the use of trade date accounting. The graph on the right (Trade vs. Settlement Date Accounting) shows the percentage of MTS participants that use trade date and settlement date accounting. In the graph, banks are weighted with their total assets held for trading (based on data from SNL Financial). The information of whether a firm uses trade date or settlement date accounting was hand-collected from 2016 annual reports. The considered MTS participants are all those that appeared in a snapshot of the member list on the MTS website taken on 21 November 2016.

Figure 4 illustrates this point by showing an example of trading relationships between five traders. They trade securities back and forth, as is usual for market makers. Their gross exposures to each other are quite substantial, whereas the net amount that they would owe to a CCP that facilitates multilateral netting would be rather small. This fact is mirrored in their balance sheets.

As an example, Figure 5 shows this process for Trader B. He sells securities worth 210 to Trader A and securities worth 90 to Trader D. At the same time, he also buys securities worth 120 from Trader $C$ and securities worth 160 from Trader E. This means that if Trader $\mathrm{B}$ uses trade date accounting and no CCP is used, then he has to account for liabilities worth 280 and receivables worth 300 (for the time between the trade and settlement date). 
This is because all trades are executed with different counterparties, and netting is not feasible (right side). However, if a CCP is used, he only has to account for a net liability of 20 towards the CCP (left side).

\section{Bilateral Relationships}

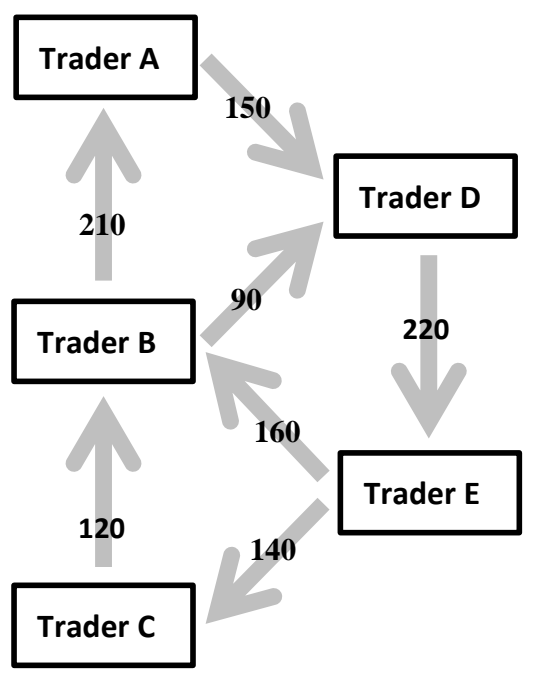

Multilateral Netting

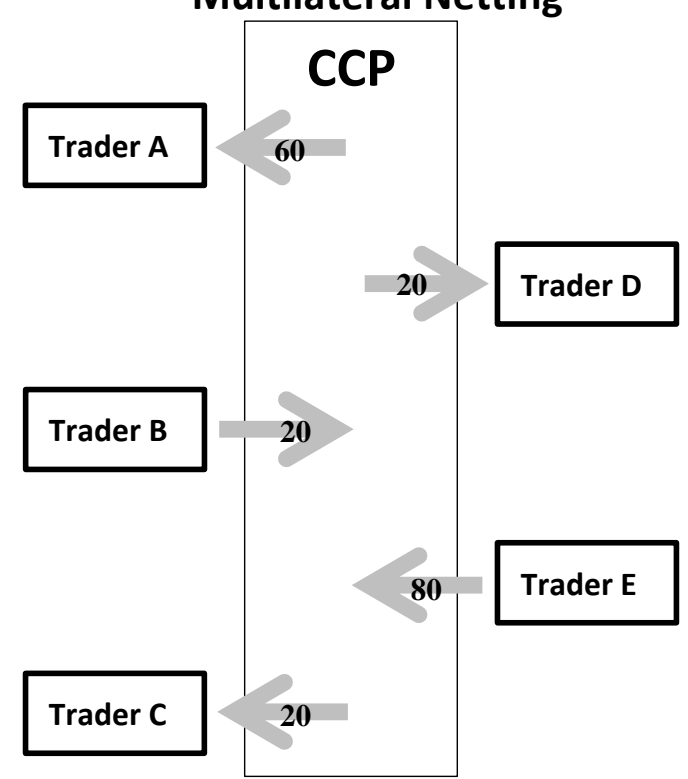

Figure 4. Bilateral trading relationships and multilateral netting. The figure shows trading relationships among five traders, named A, B, C, D and E. The graph on the left shows their bilateral relationships. The arrows represent the cash flows (bonds flow in the opposite direction). The number attached to the arrow represents the value of the bonds exchanged. The graph on the right illustrates multilateral netting. The CCP is the counterparty for each trader. The traders just receive or deliver the netted amount to the CCP.

This balance sheet expansion directly translates into an increase in the exposure measure used to calculate the Basel III leverage ratio and, thus, ultimately, the equity that a dealer must hold to comply with the leverage rule. Below, we illustrate how much equity dealers need to support these trading activities in different scenarios. In the absence of the leverage rule, the position of Trader B in the example is almost self-financing. He only has to finance the net position of 20 securities. Assuming a haircut of $1.5 \%$, the market maker only needs 0.3 to finance the position. However, if there is a $3 \%$ leverage rule, the market maker requires $9(300 \times 3 \%)$ in equity to hold this position. If the CCP is used, the impact of the leverage rule on equity requirements is substantially attenuated. The required equity is only $0.6(40 \times 3 \%)$. This simple example illustrates the importance of the balance sheet effects of CCPs on the market-making activities of banks. The leverage rule increases the cost of using balance sheet space. 
Initial Balance Sheet of trader B ( $\mathrm{T}=0)$

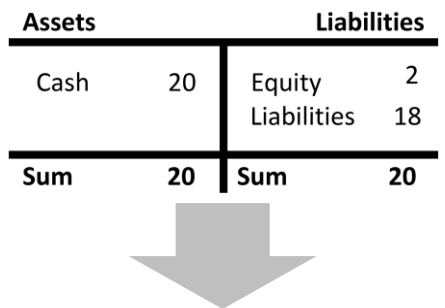

Trades occur ( $T=1)$ : Trader B buys bonds worth 210 from Trader A and 90 from Trader D and sells bonds worth 120 and 160 to Trader $C$ and Trader $E$ with settlement in T+2

CCP NOT used
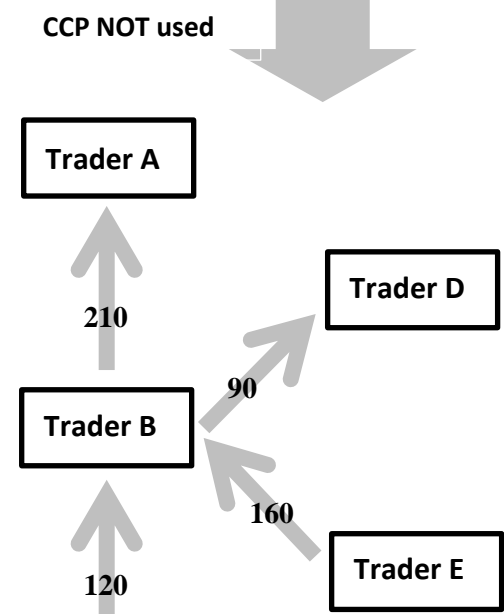

Trader C

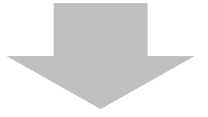

CCP used

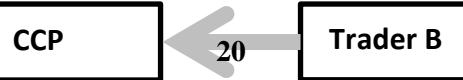

Balance sheets between $\mathrm{T}=1$ (trading) and $\mathrm{T}=\mathbf{3}$ (settlement)

\begin{tabular}{lr|lr} 
Assets & & & Liabilities \\
\hline Bonds & 20 & Equity & 2 \\
Cash & 20 & Liabilities & 318 \\
Receivables & 280 & & \\
\hline Sum & $\mathbf{3 2 0}$ & Sum & $\mathbf{3 2 0}$
\end{tabular}

\begin{tabular}{lr|lr} 
Assets & & \multicolumn{2}{r}{ Liabilities } \\
\hline Cash & 20 & Equity & 2 \\
Bonds & 20 & Liabilities & 38 \\
\hline Sum & $\mathbf{4 0}$ & Sum & $\mathbf{4 0}$
\end{tabular}

Figure 5. Example of dealer balance sheet. This figure shows the development of the balance sheet of a trader between settlement and trade date depending on whether CCP services are used or not. The top shows exemplary initial balance sheets of the fictitious dealer B. It is assumed that this dealer buys bonds worth 210 from Trader A and 90 from Trader D and sells bonds worth 120 (160) to dealer $\mathrm{C}(\mathrm{E})$ at time $\mathrm{T}=1$. The left-hand side of the figure shows the bilateral trading relationships as well as the balance sheet between trade and settlement date $(\mathrm{T}=3)$ without the use of a $C C P$, while the right-hand side shows the case with the involvement of a CCP (all dealers are members of the CCP, and transactions can be netted).

\section{Data}

We used high-frequency trade and quote data from the electronic interdealer platform MTS, covering the period from January 2012 to December 2014. Data from MTS provide a comprehensive and representative picture of the European sovereign bond market (Östberg and Richter (2017)). The MTS data set is organized into three types of files available on a monthly basis: reference files that contain bond characteristics, fills files that contain trade-by-trade data and the best proposal files encompassing all quote updates (millisecond timestamps). 
We only considered zero-coupon and straight bonds issued by the central government of selected European sovereigns. Among the countries whose bonds are traded on MTS, we focused on the following European countries: Austria (AT), Belgium (BE), Finland (FI), Italy (IT), Germany (DE), Ireland (IE) and The Netherlands (NL). We excluded extremely thinly traded countries (e.g., Luxembourg and Slovenia), countries lacking variation in CCP usage in our sample period (Spain, France, Portugal and Greece) and countries that do not use the euro as their currency (Denmark, Israel and the UK). Additionally, we corrected known errors in the MTS data set and applied standard screens to trade- and quote-level data. $^{16}$

Of special interest in this paper is the CCP flag variable, which indicates whether each trade was executed with the involvement of a CCP or not. We consider the group of trades that do not involve CCPs to be exposed to the introduction of the leverage ratio because these trades require, as explained in Section 2.3, a sizable amount of balance sheet space compared to trades that are cleared via a CCP. We thus refer to this group as the treated group. In contrast, we refer to the group of trades that are routed via a CCP and are thus less affected by the new leverage requirements as the control group. Having defined these groups, we used these data to calculate daily measures of our variable of interest: trading activity at the bond-day-group level. Additionally, we calculated a number of control variables that represent the trade and bond characteristics of a particular bond (see Section 4 for details regarding the definition of the variables).

Overall, our sample contains 212,058 bond-day observations, which corresponds to 428,318 bond-day-group observations. If one considers only non-zero-trading days, 114,958 bond-day-group observations remain. Approximately $43 \%$ of these observations $(48,885)$ are in the treated group, while the remaining $57 \%$ of these observations $(66,073)$ are in the control group. The sample covers 595 bonds and 759 trading days. ${ }^{17}$

\section{Variables and Descriptive Statistics}

\subsection{Trading Activity}

Our main variable of interest is the traded EUR volume. For each bond $i$ in each group $g$ on each day $t$, we calculated the sum of the traded amounts in EUR across all trades $j$ in order to obtain the daily bond-group-level euro volume $V O L_{i, t, g}$. One group contains all trades that are not routed via a CCP (treated group), and the other group contains all trades that are (control group). Panel A of Table 3 contains descriptive statistics for the EUR volume. The average traded amount per bond and day is EUR 39.40 million and ranges from EUR 2.62 million to EUR 99.45 million from the 5\% to 95\% quantile. The standard deviation of the daily average trading activity per bond is 56.54 and is driven by variation both across bonds and over time.

The average trading volume in the treated group (no CCP is used) is only EUR 29.81 million, while it is 46.49 million in the control group (CCP is used). Trading activity in this period is characterized by recovery from low crisis levels. Consistent with the hypothesis that the use of CCPs has been beneficial for market making since the introduction of the leverage rule, the recovery is only visible for the control group (increases by $47.1 \%$ ), while the treatment group volume drops slightly (decreases by $11.2 \%$ ).

Besides the euro volume, we also studied the number of bonds traded to confirm that our results are not explained by price changes in certain groups of bonds. Panel B of Table 3 shows descriptive statistics for the number of traded bonds. The mean number of bonds that are traded per day and group is 379,363 . For the euro volume, the number of bonds traded is recovering from low crisis values, and the recovery is more pronounced for the control group than for the treatment group. 
Table 3. Descriptive statistics for volume and liquidity.

\begin{tabular}{lrrrrrr}
\hline & Count & Mean & p50 & sd & p5 & p90 \\
\hline Panel A: Euro Volume (expressed in millions) & 114,958 & 39.40 & 19.82 & 56.54 & 2.62 & 99.45 \\
VOL & 48,885 & 29.81 & 12.51 & 46.55 & 2.41 & 71.26 \\
VOL treated & 66,073 & 46.49 & 23.07 & 61.98 & 3.41 & 115.71 \\
VOL control & 63,327 & 43.29 & 20.44 & 59.73 & 2.94 & 110.48 \\
VOL post & 26,956 & 28.42 & 12.48 & 41.68 & 2.29 & 69.50 \\
VOL post treated & 36,371 & 54.31 & 28.68 & 68.11 & 4.91 & 135.84 \\
VOL post control & 51,631 & 34.62 & 16.73 & 51.97 & 2.52 & 84.06 \\
VOL pre & 21,929 & 31.51 & 12.57 & 51.86 & 2.48 & 78.91 \\
VOL pre treated & 29,702 & 36.91 & 19.93 & 51.93 & 2.63 & 88.68 \\
VOL pre control & & & & & \\
Panel B: Number of bonds traded & 114,958 & 379,363 & 190,000 & 555,079 & 25,000 & 960,000 \\
NOB & 48,885 & 284,432 & 110,000 & 459,060 & 20,000 & 700,000 \\
NOB treated & 66,073 & 449,600 & 210,000 & 607,093 & 30,000 & $1,120,000$ \\
NOB control & 63,327 & 414,477 & 200,000 & 583,603 & 25,000 & $1,070,000$ \\
NOB post & 26,956 & 270,767 & 110,000 & 410,610 & 20,000 & 650,000 \\
NOB post treated & 36,371 & 520,987 & 270,000 & 664,394 & 50,000 & $1,310,000$ \\
NOB post control & 51,631 & 336,295 & 150,000 & 514,698 & 25,000 & 815,000 \\
NOB pre & 21,929 & 301,229 & 105,000 & 511,887 & 25,000 & 750,000 \\
NOB pre treated & 29,702 & 362,185 & 200,000 & 515,242 & 25,000 & 870,000 \\
NOB pre control & & & & & & \\
\hline Panel C: Bid-Ask Spreads & 212,058 & $0.240 \%$ & $0.089 \%$ & $0.631 \%$ & $0.006 \%$ & $0.475 \%$ \\
BAS & 82,475 & $0.180 \%$ & $0.080 \%$ & $0.426 \%$ & $0.004 \%$ & $0.413 \%$ \\
BAS treated & 129,583 & $0.280 \%$ & $0.098 \%$ & $0.729 \%$ & $0.013 \%$ & $0.512 \%$ \\
BAS control & 109,521 & $0.130 \%$ & $0.064 \%$ & $0.365 \%$ & $0.005 \%$ & $0.304 \%$ \\
BAS post & 43,469 & $0.120 \%$ & $0.061 \%$ & $0.475 \%$ & $0.003 \%$ & $0.209 \%$ \\
BAS post treated & 66,052 & $0.140 \%$ & $0.067 \%$ & $0.269 \%$ & $0.011 \%$ & $0.339 \%$ \\
BAS post control & 102,537 & $0.360 \%$ & $0.152 \%$ & $0.810 \%$ & $0.010 \%$ & $0.692 \%$ \\
BAS pre & 39,006 & $0.240 \%$ & $0.148 \%$ & $0.352 \%$ & $0.005 \%$ & $0.561 \%$ \\
BAS pre treated & 63,531 & $0.420 \%$ & $0.155 \%$ & $0.985 \%$ & $0.018 \%$ & $0.842 \%$ \\
BAS pre control & & & & & \\
\hline
\end{tabular}

Panel A contains descriptive statistics for the euro volume $(V O L)$, which is calculated as the trade price times the number of bonds traded and expressed in millions of euros. Panel B contains the number of bonds traded (NOB) calculated from the nominal trading volume provided by MTS divided by the nominal value of the bond. Panel $C$ contains the statistics for the bid-ask spreads $(B A S)$ calculated as a daily average of the difference between the best ask and bid price divided by the mid-price. The reported descriptive statistics include the number of bond-day observations (N), the mean (mean), the median (p50), the 5 percent quantile (p5) and the 95 percent quantile (p95). These statistics are calculated from bond-day observations across all bonds and over the entire sample period. In each panel, we report the statistics for the entire sample, the treated group, the control group, and before (pre) and after (post) the introduction of Basel III for both the treated and control groups.

\subsection{Liquidity}

Besides trading activity, we are also interested in the impact of the leverage regulation on sovereign bond liquidity. Quotes can be posted by both market makers that are members of a CCP and those that are not. Similarly, members and non-members of the CCP can hit these quotes. Thus, there is no distinction between liquidity for $\mathrm{CCP}$ and non-CCP members. However, the likelihood that a trade is executed with the involvement of a CCP substantially differs across securities. ${ }^{18}$ We calculated this likelihood for the entire sample period and then divided securities on a country-by-country basis into groups at or below and above the median, again yielding treated (low likelihood of CCP usage) and control groups (high likelihood of CCP usage). We calculated average bid-ask spreads $B A S_{i, t}$ for each bond $i$ and each day $t$ as follows:

$$
B A S_{i, t}=\frac{1}{K_{i, t}} \sum_{k=1}^{K_{i, t}}\left(\frac{P_{i, t, k}^{A}-P_{i, t, k}^{B}}{P_{i, t, k}^{M}}\right) .
$$

where $P_{i, t, k}^{A}\left(P_{i, t, k}^{B}\right)$ is the best ask price (bid price) quoted on the MTS platform after update $k$ for bond $i$ on day $t$. Panel $C$ of Table 3 shows descriptive statistics for this variable. The average bond is traded with a bid-ask spread (round-trip cost) of $0.240 \%$. Consistent with increasing volume, bid-ask spreads decreased during our sample period. The trading costs in the treated group are lower than those in the control group $(0.180 \%$ vs. $0.280 \%)$. 


\subsection{Control Variables}

We used information about bond and trade characteristics contained in the MTS data set to search for systematic differences between the treated and control groups and then used these variables as control variables in our empirical analysis. Table 4 shows descriptive statistics for the control variables for the entire sample, the control and treated groups and the difference between the treated and control groups. We tested whether the difference is statistically significant using dummy regressions and standard errors that are clustered around bond codes.

Table 4. Trade and quote characteristics.

\begin{tabular}{|c|c|c|c|c|}
\hline & Overall & Control & Treated & Difference \\
\hline $\begin{array}{l}\text { Panel A: Trade Characteristics } \\
\text { Euro Volume (mn) } \\
\text { Number of bonds traded } \\
\text { Trade size } \\
\text { Share of buy trades } \\
\text { Share of partially filled trades } \\
\text { Share of price taker trades } \\
\text { Share EBM market }\end{array}$ & $\begin{array}{r}39.3965 \\
37.9363 \\
6.4365 \\
0.5074 \\
0.1497 \\
0.0447 \\
0.1072\end{array}$ & $\begin{array}{r}46.4909 \\
44.9600 \\
6.1187 \\
0.5055 \\
0.1672 \\
0.0400 \\
0.0710\end{array}$ & $\begin{array}{r}29.8078 \\
28.4432 \\
6.8660 \\
0.5100 \\
0.1259 \\
0.0511 \\
0.1561\end{array}$ & $\begin{array}{r}-16.683^{* * *} \\
-16.517^{* * * *} \\
0.747^{* * *} \\
0.004^{* *} \\
-0.041^{* * *} \\
0.011^{* * *} \\
0.085^{* * *}\end{array}$ \\
\hline $\begin{array}{l}\text { Panel B: Bond Characteristics } \\
\text { Number of Settlement days } \\
\text { Number of participants } \\
\text { Number of market makers } \\
\text { Age } \\
\text { Original maturity }\end{array}$ & $\begin{array}{r}2.7177 \\
53.9129 \\
13.7357 \\
3.3258 \\
9.3472\end{array}$ & $\begin{array}{r}2.7056 \\
63.2776 \\
11.4364 \\
3.3242 \\
9.0077\end{array}$ & $\begin{array}{r}2.734 \\
41.2555 \\
17.5188 \\
3.328 \\
9.8061\end{array}$ & $\begin{array}{r}0.028^{*} \\
-22.022^{* * *} \\
6.082^{* * *} \\
0.004 \\
0.798\end{array}$ \\
\hline $\begin{array}{l}\text { Panel C: Quote Characteristics } \\
\text { Relative bid-ask spread } \\
\text { Quoted quantity at bid } \\
\text { Quoted quantity at ask } \\
\text { Mid-Price } \\
\text { Volatility (price returns) } \\
\text { Price returns }\end{array}$ & $\begin{array}{r}0.0024 \\
12.777 \\
12.652 \\
106.422 \\
0.0001 \\
0.0002\end{array}$ & $\begin{array}{r}0.0028 \\
11.838 \\
11.687 \\
108.3222 \\
0.0002 \\
0.0002\end{array}$ & $\begin{array}{r}0.0018 \\
14.254 \\
14.168 \\
103.4365 \\
0.0001 \\
0.0002\end{array}$ & $\begin{array}{r}-0.001^{* * *} \\
2.416^{* * *} \\
2.480^{* * *} \\
-4.886^{* * *} \\
-0.000^{* *} \\
0.0000\end{array}$ \\
\hline
\end{tabular}

This table contains the means for selected trade, quote and bond characteristics that were used in the regression analysis. The table reports the means for the overall sample, means for the treated and control groups and the difference in the means between the treated and control groups. The significance is based on a two-sample $t$-test, and standard errors are adjusted for clustering at the bond level. Panel A contains trade characteristics. The euro volume $(V O L)$ is calculated as the trade price times the number of bonds traded and expressed in millions of euros and then averaged over each trading day for each bond. The number of bonds traded is calculated from the nominal trading volume provided by MTS divided by the nominal value of the bond and then averaged over each trading day for each bond. The trade size is the average euro volume of a trade. The share of buy trades is the percentage of trades that were initiated by the buying party. The share of partially filled trades is the percentage of trades that were not completely executed. The share of price takers is the percentage of trades that were not executed by a market maker. The share EBM market is the percentage of trades that were executed via the pan-European euro bond market. The number of settlement days is the time between the agreement to trade and delivery. The number of participants is the number of active MTS members that are allowed to trade a particular bond. The number of market makers is the number of MTS participants that provide bid and ask prices for a certain bond. The age of a security is calculated as the difference in years between the current date and the issue date. The original maturity is the difference in years between the maturity date and the issue date. The relative bid-ask spread is calculated as the average difference between the bid and ask price divided by the mid-price and then averaged across all quotes for a bond on a particular day. The quoted quantity is the average volume that can be traded based on the quoted prices. The mid-price is the average price level. The volatility is calculated from intraday price returns, and price returns are calculated from the mid-prices at close. ${ }^{* * *},{ }^{* *}$ and ${ }^{*}$ denote statistical significance at the $1 \%, 5 \%$ and $10 \%$ levels, respectively.

Panel A shows the results for the trade variables. On average, CCP trades are smaller ( 0.75 million) and more likely to be only partially executed (4.1\% higher likelihood). Additionally, they are less likely to be executed by price takers (1.1\%). Moreover, CCP trades are more likely to occur on a domestic trading platform rather than a pan-European platform.

Panel B contains bond characteristics, which show that the average bond traded over a $\mathrm{CCP}$ settles faster and is traded in markets with more participants but fewer market makers. There is no significant difference in age or original maturity between CCP and non-CCP traded bonds. Bonds that are traded over CCPs also have higher bid-ask spreads and lower quoted quantities at both the bid and ask, and, on average, they trade with higher prices and are subject to higher volatility. The average price returns, however, suggest that the bonds experienced similar price movements during our sample period. There are also 
significant differences when it comes to mid-prices. The differences in these variables will be incorporated into the analysis in the following sections by either using control variables or fixed effects.

\section{Empirical Analysis}

\subsection{Trading Activity}

We argue that the introduction of the leverage rule constitutes a shock to bank balance sheets, which in turn has led to decreased trading activity in the European sovereign bond market. With the leverage rule in place, dealers are reluctant to take on positions that need a lot of balance sheet space (trading sovereign bonds without CCPs), which has become scarce with the leverage rule in place. As a result, dealers focus on trading activity that requires little balance sheet space (sovereign bond trading with CCPs). Thus, we expect non-CCP trading volume to develop less favorably than CCP trading volume.

We tested this hypothesis in a difference-in-difference regression framework, where we explain the EUR volume with the interaction term NoCCP $\times$ Post (captures the differential reaction of the non-CCP group to the Basel III leverage rule introduction), a NoCCP dummy (controls for differences between the two groups), a Post dummy (controls for differences between the two time periods) and a set of control variables (described in Section 4.3). Post is a dummy that takes a value of 0 before 26 June 2013 (the EU implementation of Basel III) and 1 afterwards. NoCCP is a dummy that takes a value of 1 for the group of trades that were not routed via a CCP and 0 for the other group. In this baseline specification, we estimated the following regression:

$$
V O L_{i, t, g}=\alpha+\beta N o C C P_{i, g}+\gamma \text { Post }_{t}+\delta\left(\text { NoCCP }_{i, g} \times \text { Post }_{t}\right)+\Gamma^{\prime} \boldsymbol{W}_{i, t}+u_{i, t, g}
$$

where $\boldsymbol{W}_{i, t}$ and $\boldsymbol{\Gamma}$ are vectors with control variables and regression coefficients, respectively. To control for unobserved variables, we saturated our model with a set of fixed effects. In the most elaborate model, we used Bond $\times$ NoCCP and Country $\times$ Time fixed effects. As a result, we confirmed that country-specific time trends and bond-specific characteristics are not captured by the $\operatorname{NoCCP}_{i, g} \times$ Post $_{t}$ interaction effect. Ideally, we would also introduce market maker fixed effects, but the MTS data set does not contain this information. However, using Bond $\times$ NoCCP fixed effects and control variables for trading characteristics, we at least partially mitigate this issue since different market makers focus on different bonds and exhibit certain trading patterns. The fully saturated model that we estimated is as follows:

$$
V O L_{i, t, g}=\alpha_{i, g}+\alpha_{t, c}+\delta\left(\operatorname{NoCCP}_{i, g} \times \text { Post }_{t}\right)+\Gamma^{\prime} \boldsymbol{W}_{i, t}+u_{i, t, g}
$$

where $\alpha_{i, g}$ and $\alpha_{t, c}$ are Bond $\times$ NoCCP fixed effects and Country $\times$ Time fixed effects, respectively. Table 5 contains the results of these regressions. The standard errors are two-way clustered around both bond and time.

The first column shows the estimation of the baseline model from Equation (2). We are particularly interested in the $\delta$ coefficient. The results show that, as predicted, trading activity has developed less favorably for the treatment group, in which a CCP is not used. The trading activity is EUR 20.1 million lower than it would have been if the trading activity in this group had developed in the same way as in the control group (in which CCPs are used). This is an economically significant decrease of approximately $50 \%$ of the mean trading volume for the average bond on an average day. The decrease is also statistically significant at the $1 \%$ level.

This drop seems large but should be interpreted with caution since this model is not saturated with fixed effects. In columns (2)-(5), more fixed effects are added to the equation step-by-step. The model estimated in column (2) adds bond fixed effects, the one in column (3) contains both bond and time fixed effects, the estimates in column (4) are based on Bond $\times$ NoCCP fixed effects and the model in column (5) contains both Bond $\times$ NoCCP and time fixed effects. Even though the $\delta$ coefficient notably decreases in 
all of these specifications compared to specification (1), it remains statistically significant at the $1 \%$ or $5 \%$ level.

Table 5. Difference-in-difference in EUR volume.

\begin{tabular}{|c|c|c|c|c|c|c|}
\hline & (1) & (2) & (3) & (4) & (5) & (6) \\
\hline NoCCP & $\begin{array}{c}-5.081^{* * *} \\
(-2.61)\end{array}$ & $\begin{array}{l}2.068 \\
(1.13)\end{array}$ & $\begin{array}{l}1.758 \\
(0.94)\end{array}$ & & & \\
\hline Post & $\begin{array}{c}17.848^{* * * *} \\
(7.80)\end{array}$ & $\begin{array}{c}6.236^{* * *} \\
(2.78)\end{array}$ & & $\begin{array}{l}2.678 \\
(1.21)\end{array}$ & & \\
\hline Post $\times$ NoCCP & $\begin{array}{c}-20.112 * * * \\
(-7.19)\end{array}$ & $\begin{array}{c}-13.590^{* * *} \\
(-5.34)\end{array}$ & $\begin{array}{c}-13.467^{* * *} \\
(-5.19)\end{array}$ & $\begin{array}{c}-4.771 * * \\
(-2.49)\end{array}$ & $\begin{array}{c}-4.449^{* *} \\
(-2.30)\end{array}$ & $\begin{array}{c}-2.710^{* *} \\
(-2.36)\end{array}$ \\
\hline sd & $\begin{array}{c}-2.300 * * * \\
(-3.82)\end{array}$ & $\begin{array}{l}1.219 * * * \\
(2.76)\end{array}$ & $\begin{array}{c}1.531^{* * *} \\
(3.18)\end{array}$ & $\begin{array}{c}1.396^{* * *} \\
(2.96)\end{array}$ & $\begin{array}{c}1.690 * * * \\
(3.24)\end{array}$ & $\begin{array}{c}2.519 * * * \\
(4.27)\end{array}$ \\
\hline Return & $\begin{array}{l}-0.862 * \\
(-1.76)\end{array}$ & $\begin{array}{c}-0.808^{* *} \\
(-2.13)\end{array}$ & $\begin{array}{l}-0.593 \\
(-1.45)\end{array}$ & $\begin{array}{c}-0.773^{* *} \\
(-1.97)\end{array}$ & $\begin{array}{l}-0.604 \\
(-1.46)\end{array}$ & $\begin{array}{l}-0.035 \\
(-0.09)\end{array}$ \\
\hline Mid-Price & $\begin{array}{l}-0.002 * * \\
(-2.00)\end{array}$ & $\begin{array}{l}0.002^{* * *} \\
(2.68)\end{array}$ & $\begin{array}{c}0.003^{* * *} \\
(3.42)\end{array}$ & $\begin{array}{c}0.003^{* * *} \\
(3.31)\end{array}$ & $\begin{array}{c}0.004^{* * *} \\
(3.92)\end{array}$ & $\begin{array}{l}0.001 \\
(0.38)\end{array}$ \\
\hline Age & $\begin{array}{c}-0.018 * * * \\
(-7.80)\end{array}$ & $\begin{array}{l}0.010 \\
(0.81)\end{array}$ & & $\begin{array}{l}-0.002 \\
(-0.12)\end{array}$ & & \\
\hline Order Status & $\begin{array}{c}0.228^{* * *} \\
(21.55)\end{array}$ & $\begin{array}{c}0.158^{* * *} \\
(17.20)\end{array}$ & $\begin{array}{c}0.158 * * * \\
(17.43)\end{array}$ & $\begin{array}{c}0.167^{* * *} \\
(18.38)\end{array}$ & $\begin{array}{c}0.166^{* * *} \\
(18.74)\end{array}$ & $\begin{array}{c}0.164 * * * \\
(19.93)\end{array}$ \\
\hline$\%$ Market Taker & $\begin{array}{c}-0.104^{* * *} \\
(-11.22)\end{array}$ & $\begin{array}{c}-0.121^{* * *} \\
(-11.90)\end{array}$ & $\begin{array}{c}-0.120 * * * \\
(-11.81)\end{array}$ & $\begin{array}{c}-0.033^{* * *} \\
(-5.01)\end{array}$ & $\begin{array}{c}-0.030^{* * *} \\
(-4.42)\end{array}$ & $\begin{array}{c}-0.025^{* * *} \\
(-3.44)\end{array}$ \\
\hline$\%$ EBM & $\begin{array}{c}-0.146^{* * *} \\
(-18.70)\end{array}$ & $\begin{array}{c}-0.190^{* * *} \\
(-15.76)\end{array}$ & $\begin{array}{c}-0.197 * * * \\
(-15.44)\end{array}$ & $\begin{array}{c}-0.028^{* * *} \\
(-6.26)\end{array}$ & $\begin{array}{c}-0.032 * * * \\
(-6.62)\end{array}$ & $\begin{array}{c}-0.035^{* * * *} \\
(-6.79)\end{array}$ \\
\hline$\%$ Buys & $\begin{array}{c}-1.732^{* * *} \\
(-4.32)\end{array}$ & $\begin{array}{c}-1.743^{* * *} \\
(-5.21)\end{array}$ & $\begin{array}{c}-1.726^{* * *} \\
(-5.39)\end{array}$ & $\begin{array}{c}-2.028^{* * *} \\
(-5.82)\end{array}$ & $\begin{array}{c}-2.001^{* * * *} \\
(-6.06)\end{array}$ & $\begin{array}{c}-1.744^{* * *} \\
(-5.85)\end{array}$ \\
\hline Trade Size & $\begin{array}{c}2.960 * * * \\
(16.93)\end{array}$ & $\begin{array}{c}4.009 * * * \\
(27.17)\end{array}$ & $\begin{array}{l}3.992^{* * *} \\
(27.54)\end{array}$ & $\begin{array}{c}3.919^{* * * *} \\
(28.50)\end{array}$ & $\begin{array}{c}3.895^{* * *} \\
(28.93)\end{array}$ & $\begin{array}{c}3.860 * * * \\
(30.92)\end{array}$ \\
\hline $\mathrm{N}$ & 114,958 & 114,958 & 114,958 & 114,958 & 114,958 & 114,958 \\
\hline$R^{2}$ & 0.111 & 0.205 & 0.232 & 0.269 & 0.298 & 0.328 \\
\hline Bond FE & No & Yes & Yes & No & No & No \\
\hline Time FE & No & No & Yes & No & Yes & No \\
\hline Bond $\times$ NoCCP FE & No & No & No & Yes & Yes & Yes \\
\hline Country $\times$ Time FE & No & No & No & No & No & Yes \\
\hline Cluster & TW & TW & TW & TW & TW & TW \\
\hline
\end{tabular}

This table contains point estimates of the coefficients as well as $t$-statistics (in parentheses) from estimating the following regression: $V O L_{i, t, g}=\alpha_{i, g}+\alpha_{t, c}+\delta\left(N o C C P_{i, g} \times P_{o s} t_{t}\right)+\boldsymbol{\Gamma}^{\prime} \boldsymbol{W}_{i, t}+u_{i, t, g}$. This analysis was conducted at the day-bond-group level. The sample covers the period between 1 January 2012 and 31 December 2014 . The dependent variable is the group euro volume $(V O L)$. The trades are assigned to the treated group if the trade was not handled with the involvement of a CCP and to a control group if the trade was executed with the involvement of a CCP. Based on this categorization, we created the variable NoCCP, which takes a value of 1 for the treated group and 0 for the control group. The variable Post takes a value of 1 after 26 June 2013 and 0 afterwards. The vector $\boldsymbol{W}_{i, t}$ contains the control variables described in Section 4.3. The standard errors are two-way clustered around time and bond. ${ }^{* * *},{ }^{* *}$ and ${ }^{*}$ denote statistical significance at the $1 \%, 5 \%$ and $10 \%$ levels, respectively.

The results of estimating the most elaborate model, which includes Country $\times$ Time and Bond $\times$ NoCCP fixed effects (Equation (3)), are presented in column (6). The $\delta$ coefficient associated with the interaction term NoCCP $\times$ Post indicates a decrease of EUR 2.71 million, which corresponds to a decrease of $6.9 \%$ relative to the unconditional mean and is statistically significant at the $5 \%$ level. Overall, this confirms the hypothesis that the leverage rule impairs market-making activities that are balance-sheet-intensive (market-making activities without the use of CCPs).

Consistent with the results for the EUR volume, we find equivalent results if we use the number of bonds traded $\left(N O B_{i, t, g}\right)$ instead. In the most saturated model (specification (6) in Table 6 ) with both Country $\times$ Time and Bond $\times$ NoCCP fixed effects, the number of shares traded is reduced by 197,000 in the non-CCP group following the introduction of the leverage rule, which is statistically significant at the $10 \%$ confidence interval. 
Table 6. Difference-in-difference with number of bonds traded.

\begin{tabular}{|c|c|c|c|c|c|c|}
\hline & (1) & (2) & (3) & (4) & (5) & (6) \\
\hline $\mathrm{NoCCP}$ & $\begin{array}{c}-0.511^{* * *} \\
(-2.68)\end{array}$ & $\begin{array}{l}0.177 \\
(0.99)\end{array}$ & $\begin{array}{l}0.147 \\
(0.80)\end{array}$ & & & \\
\hline Post & $\begin{array}{c}1.682^{* * *} \\
(7.50)\end{array}$ & $\begin{array}{c}0.583^{* * *} \\
(2.66)\end{array}$ & & $\begin{array}{l}0.224 \\
(1.04)\end{array}$ & & \\
\hline Post $\times$ NoCCP & $\begin{array}{c}-1.899 * * * \\
(-6.87)\end{array}$ & $\begin{array}{l}-1.267^{* * * *} \\
(-5.09)\end{array}$ & $\begin{array}{l}-1.255^{* * *} \\
(-4.94)\end{array}$ & $\begin{array}{l}-0.380 * * \\
(-2.04)\end{array}$ & $\begin{array}{l}-0.347^{*} \\
(-1.85)\end{array}$ & $\begin{array}{l}-0.197 * \\
(-1.80)\end{array}$ \\
\hline sd & $\begin{array}{l}-0.251^{* * *} \\
(-4.08)\end{array}$ & $\begin{array}{l}0.104^{* *} \\
(2.54)\end{array}$ & $0.136^{* * * *}$ & $0.121^{* * * *}$ & $\begin{array}{c}0.152 * * * \\
(3.14)\end{array}$ & $\begin{array}{c}0.236 * * * \\
(4.24)\end{array}$ \\
\hline Return & $\begin{array}{l}-0.074 \\
(-1.62)\end{array}$ & $\begin{array}{l}-0.062 \\
(-1.73)\end{array}$ & $\begin{array}{l}-0.040 \\
(-1.03)\end{array}$ & $\begin{array}{l}-0.059 \\
(-1.60)\end{array}$ & $\begin{array}{l}-0.042 \\
(-1.07)\end{array}$ & $\begin{array}{l}0.013 \\
(0.35)\end{array}$ \\
\hline Mid-Price & $\begin{array}{c}-0.000 * * * \\
(-4.01)\end{array}$ & $\begin{array}{l}-0.000 \\
(-0.04)\end{array}$ & $\begin{array}{l}0.000 \\
(0.95)\end{array}$ & $\begin{array}{l}0.000 \\
(0.94)\end{array}$ & $\begin{array}{c}0.000 * \\
(1.78)\end{array}$ & $\begin{array}{l}-0.000 \\
(-1.11)\end{array}$ \\
\hline Age & $\begin{array}{c}-0.002 * * * \\
(-7.96)\end{array}$ & $\begin{array}{l}0.001 \\
(0.68)\end{array}$ & & $\begin{array}{l}-0.000 \\
(-0.24)\end{array}$ & & \\
\hline Order Status & $\begin{array}{l}0.022 * * * \\
(21.07)\end{array}$ & $\begin{array}{c}0.015^{* * *} \\
(16.75)\end{array}$ & $\begin{array}{c}0.015^{* * *} \\
(16.99)\end{array}$ & $\begin{array}{c}0.016^{* * *} \\
(17.85)\end{array}$ & $\begin{array}{c}0.016^{* * *} \\
(18.20)\end{array}$ & $\begin{array}{c}0.016 \text { *** } \\
(19.32)\end{array}$ \\
\hline$\%$ Market Taker & $\begin{array}{c}-0.010 * * * \\
(-11.47)\end{array}$ & $\begin{array}{l}-0.012 * * * \\
(-11.88)\end{array}$ & $\begin{array}{c}-0.012^{* * *} \\
(-11.75)\end{array}$ & $\begin{array}{c}-0.003^{* * *} \\
(-4.89)\end{array}$ & $\begin{array}{c}-0.003^{* * *} \\
(-4.25)\end{array}$ & $\begin{array}{c}-0.002^{* * * *} \\
(-3.30)\end{array}$ \\
\hline$\%$ EBM & $\begin{array}{c}-0.014^{* * *} \\
(-18.36)\end{array}$ & $\begin{array}{l}-0.018 \text { *** } \\
(-15.58)\end{array}$ & $\begin{array}{c}-0.019 * * * \\
(-15.30)\end{array}$ & $\begin{array}{c}-0.003^{* * * *} \\
(-6.01)\end{array}$ & $\begin{array}{c}-0.003^{* * *} \\
(-6.40)\end{array}$ & $\begin{array}{c}-0.003^{* * * *} \\
(-6.60)\end{array}$ \\
\hline$\%$ Buys & $\begin{array}{c}-0.169 * * * \\
(-4.26)\end{array}$ & $\begin{array}{c}-0.169 * * * \\
(-5.12)\end{array}$ & $\begin{array}{c}-0.166^{* * *} \\
(-5.27)\end{array}$ & $\begin{array}{c}-0.198^{* * *} \\
(-5.75)\end{array}$ & $\begin{array}{c}-0.194^{* * *} \\
(-5.96)\end{array}$ & $\begin{array}{c}-0.169 * * * \\
(-5.78)\end{array}$ \\
\hline Trade Size & $\begin{array}{c}0.288^{* * *} \\
(16.39)\end{array}$ & $\begin{array}{c}0.389 * * * \\
(26.46)\end{array}$ & $\begin{array}{c}0.387^{* * *} \\
(26.83)\end{array}$ & $\begin{array}{c}0.380 * * * \\
(27.76)\end{array}$ & $\begin{array}{c}0.378^{* * *} \\
(28.20)\end{array}$ & $\begin{array}{c}0.375^{* * * *} \\
(30.15)\end{array}$ \\
\hline $\mathrm{N}$ & 114,958 & 114,958 & 114,958 & 114,958 & 114,958 & 114,958 \\
\hline$R^{2}$ & 0.117 & 0.213 & 0.239 & 0.277 & 0.305 & 0.335 \\
\hline Bond FE & No & Yes & Yes & No & No & No \\
\hline Time FE & No & No & Yes & No & Yes & No \\
\hline Bond $\times$ NoCCP FE & No & No & No & Yes & Yes & Yes \\
\hline Country $\times$ Time FE & No & No & No & No & No & Yes \\
\hline Cluster & TW & TW & TW & TW & TW & TW \\
\hline
\end{tabular}

This table contains point estimates of the coefficients as well as $t$-statistics (in parentheses) from estimating the following regression: $N O B_{i, t, g}=\alpha_{i, g}+\alpha_{t, c}+\delta\left(N o C C P_{i, g} \times\right.$ Post $\left._{t}\right)+\Gamma^{\prime} \boldsymbol{W}_{i, t}+u_{i, t, g}$. This analysis was conducted at the day-bond-group level. The sample covers the period between 1 January 2012 and 31 December 2014. The dependent variable is the group number of bonds traded $(N O B)$. The trades were assigned to the treated group if the trade was not handled with the involvement of a CCP and to the control group if the trade was executed with the involvement of a CCP. Based on this categorization, we created the variable NoCCP, which takes a value of 1 for the treated group and 0 for the control group. The variable Post takes a value of 1 after 26 June 2013 and 0 afterwards. The vector $\boldsymbol{W}_{i, t}$ contains the control variables described in Section 4.3. The standard errors are two-way clustered around time and bond. ${ }^{* * *},{ }^{* *}$ and * denote statistical significance at the $1 \%, 5 \%$ and $10 \%$ levels, respectively.

\subsection{Liquidity}

We argue that the decreased volume in the group without CCP usage is driven by banks quoting higher bid-ask spreads for balance-sheet-intensive trades. However, a market maker who is a member of a CCP does not know whether his quotes will be hit by a trader who is also a member of the CCP. However, we claim that, given past information about CCP usage and bond characteristics, market makers are able to reasonably estimate the probability that a CCP trade will occur. Consequently, the market maker will quote higher spreads for bonds where the likelihood of a CCP trade is low (requires more balance sheet space) and lower spreads for bonds that have a high likelihood of being traded via a CCP (netting feasible).

To verify this claim, we show that the likelihood that a CCP is used for a certain bond can be predicted by simple predictive regression. Using daily bond data, we regressed the current $C C P$ share on the share of CCP usage calculated from the last 10 days for a particular bond and past values of the variables described in Section 4.3. We estimated the following regression:

$$
C C P_{i, t}=\alpha+\beta S C C P U_{i, t-1: t-11}+\Gamma^{\prime} W_{i, t-1: t-11}+u_{i, t} .
$$

We estimated the model using the linear probability model as well as the logit and probit models. The results are reported in Table 7. The significance of the estimated coefficients, the estimated average marginal effects and the high $R^{2}(0.392-0.635)$ suggest that CCP usage is highly predictable for market makers. Thus, it is reasonable to assume that they are able to incorporate expected balance sheet usage into their quote calculations. 
Table 7. Predictive regressions of CCP usage.

\begin{tabular}{|c|c|c|c|}
\hline & LPM & Probit & Logit \\
\hline $\begin{array}{l}\text { \% share CCP usage last } 10 \text { trades } \\
\text { Average Marginal Effects }\end{array}$ & $\begin{array}{c}0.247^{* * *} \\
(14.91)\end{array}$ & $\begin{array}{c}0.737^{* * *} \\
(11.03) \\
0.1439 \\
(11.03)\end{array}$ & $\begin{array}{l}1.211^{* * *} \\
(10.76) \\
0.1398 \\
(10.78)\end{array}$ \\
\hline $\begin{array}{l}\text { Number of Observations } \\
R^{2} \\
\text { Estimation Method }\end{array}$ & $\begin{array}{c}84,653 \\
0.635 \\
\text { OLS }\end{array}$ & $\begin{array}{c}84,653 \\
0.392 \\
\mathrm{ML}\end{array}$ & $\begin{array}{c}84,653 \\
0.393 \\
M L\end{array}$ \\
\hline
\end{tabular}

This table contains point estimates of the coefficients as well as $t$-statistics (in parentheses). We estimated the following regression: $C C P_{i, t}=\alpha+\beta S C C P U_{i, t-1: t-11}+\Gamma^{\prime} W_{i, t-1: t-11}+u_{i, t}$ We estimated the model using the linear probability model (LPM) as well as logit and probit models. This analysis was conducted at the day-bond level. The sample covers the period between 1 January 2012 and 31 December 2014. The dependent variable is the CCP share for bond $i$ on day $t(B A S)$. The independent variables include the share of CCP usage from -11 to -1 as well as other bond- and trade-specific variables from the past (collected in the matrix $\Gamma$ ) that vary across time and bonds (explained in Section 4.3). Additionally, we also added CCP usage from the beginning of the sample to -12 . Standard errors are two-way clustered around time and bond. ${ }^{* *}$ denote statistical significance at the $1 \%$ $5 \%$ and $10 \%$ levels, respectively.

Having established that $\mathrm{CCP}$ usage is predictable, we show that after the leverage rule was enacted, market makers quoted lower bid-ask spreads for bonds where a higher fraction of trades is routed via CCPs. We demonstrate this by comparing the development of bid-ask spreads for two groups of bonds-the group whose CCP usage is below the country's median and the group whose CCP usage is above the country's median-before and after the introduction of the leverage rule. We estimated the following regression:

$$
B A S_{i, t}=\alpha_{i}+\alpha_{t, c}+\delta\left(\text { LCCPS }_{i} \times \text { Post }_{t}\right)+\Gamma^{\prime} W_{i, t}+u_{i, t},
$$

where $\alpha_{i}$ and $\alpha_{t, c}$ are bond and time country fixed effects. Table 8 contains the results of these regressions. The standard errors are two-way clustered around both bond and time. The coefficient of interest is the $\delta$ coefficient associated with $L_{C C P S} \times$ Post $_{i, t}$, which identifies the impact of introducing the Basel III leverage rule on quotes for bonds with a low share of CCP usage compared to those with a high share of CCP usage (above the median in a particular country). As outlined above, we expect the $\delta$ coefficient to be positive since bid-ask spreads will rise more for bonds where market making requires a lot of balance sheet space, which becomes more expensive with the leverage rule in place.

The bond code fixed effects control for time-invariant bond characteristics such as original maturity, coupon type, coupon frequency, the issuer country or the issue size. The time fixed effects control for fluctuations in macroeconomic variables, such as interest rates or economic growth, that only vary across countries but not across bonds within a country. Additionally, we include bond and trade characteristics that vary across both bonds and time (see Section 4.3 for a detailed description of the control variables).

The results of estimating different specifications of Equation (5) are collected in Table 6. The results indicate that in response to the introduction of the Basel III leverage rule, the bid-ask spreads of bonds that are not usually traded via a CCP increased to a significantly greater extent compared to those of bonds with a high likelihood of being traded via CCPs. This is consistent with the notion that banks price in balance sheet usage into their bid-ask spreads and can explain the drop in trading activity in the non-CCP market segment. This effect is present in the baseline difference-in-difference regression (1) and survives the addition of bond, time and country $\times$ time fixed effects.

In terms of economic magnitude, the increase in bid-ask spreads for the low CCP usage bonds is $0.034 \%$ ( $3.4 \mathrm{bps}$ ) for the most conservative model (saturated with bond and time $\times$ country fixed effects). This corresponds to a $7 \%$ premium over the unconditional mean of the bid-ask spread of an average bond. 
Table 8. Difference-in-difference with bid-ask spread.

\begin{tabular}{|c|c|c|c|c|c|}
\hline & (1) & (2) & (3) & (4) & (5) \\
\hline Post $\times$ LCCPS & $\begin{array}{c}0.107^{* * *} \\
(2.74)\end{array}$ & $\begin{array}{c}0.159 * * * \\
(3.14)\end{array}$ & $\begin{array}{c}0.114^{* * *} \\
(2.83)\end{array}$ & $\begin{array}{c}0.162^{* * *} \\
(3.03)\end{array}$ & $\begin{array}{c}0.034^{* *} \\
(1.97)\end{array}$ \\
\hline Post & $\begin{array}{c}-0.222^{* * *} \\
(-5.83)\end{array}$ & $\begin{array}{c}-0.200 * * * \\
(-7.04)\end{array}$ & & & \\
\hline LCCPS & $\begin{array}{c}-0.153^{* * *} \\
(-3.21)\end{array}$ & & $\begin{array}{c}-0.158^{* * *} \\
(-3.24)\end{array}$ & & \\
\hline sd & $\begin{array}{c}-0.449^{* * *} \\
(-3.05)\end{array}$ & $\begin{array}{c}-2.886^{* * *} \\
(-5.37)\end{array}$ & $\begin{array}{c}-0.428 * * * \\
(-2.93)\end{array}$ & $\begin{array}{c}-2.967^{* * *} \\
(-4.85)\end{array}$ & $\begin{array}{c}-1.106^{* * *} \\
(-6.44)\end{array}$ \\
\hline Return & $\begin{array}{c}0.056^{* * *} \\
(4.50)\end{array}$ & $\begin{array}{c}0.053^{* * *} \\
(5.04)\end{array}$ & $\begin{array}{c}0.056^{* * *} \\
(4.65)\end{array}$ & $\begin{array}{c}0.050^{* * *} \\
(4.84)\end{array}$ & $\begin{array}{c}0.030^{* * *} \\
(3.65)\end{array}$ \\
\hline Mid-Price & $\begin{array}{c}0.339 * * * \\
(8.73)\end{array}$ & $\begin{array}{c}0.250 * * * \\
(7.73)\end{array}$ & $\begin{array}{c}0.333^{* * *} \\
(8.58)\end{array}$ & $\begin{array}{l}0.241 * * * \\
(7.46)\end{array}$ & $\begin{array}{c}0.142^{* * *} \\
(3.15)\end{array}$ \\
\hline$\%$ EBM & $\begin{array}{l}0.012 \\
(1.36)\end{array}$ & $\begin{array}{l}-0.010 \\
(-0.60)\end{array}$ & $\begin{array}{l}0.016 \\
(1.64)\end{array}$ & $\begin{array}{l}-0.004 \\
(-0.23)\end{array}$ & $\begin{array}{l}-0.003 \\
(-0.78)\end{array}$ \\
\hline $\mathrm{N}$ & 212,058 & 212,058 & 212,058 & 212,058 & 212,058 \\
\hline$R^{2}$ & 0.294 & 0.515 & 0.322 & 0.543 & 0.766 \\
\hline Bond FE & $\mathrm{NO}$ & YES & $\mathrm{NO}$ & YES & YES \\
\hline Time FE & $\mathrm{NO}$ & $\mathrm{NO}$ & YES & YES & $\mathrm{NO}$ \\
\hline Country $\times$ TimeFE & $\mathrm{NO}$ & $\mathrm{NO}$ & $\mathrm{NO}$ & $\mathrm{NO}$ & YES \\
\hline
\end{tabular}

This table contains point estimates of the coefficients as well as $t$-statistics (in parentheses) from estimating the following regression: $B A S_{i, t}=\alpha_{i}+\alpha_{t, c}+\beta\left(L C C P U_{i} \times\right.$ Post $\left._{t}\right)+\Gamma W_{i, t}+u_{i, t}$. This analysis was conducted at the day-bond level. The sample covers the period between 1 January 2012 and 31 December 2014. The dependent variable is the relative bid-ask spread $(B A S)$. The quotes/bonds are assigned to the treated group if the share of CCP trades for a bond is below the median for all bonds in a particular country (LCCPU). Based on this categorization, we created the variable Treat, which takes a value of 1 for the treated group and 0 for the control group. The variable Post takes a value of 0 before 26 June 2013 and 1 afterwards. The matrix $\Gamma$ contains the control variables described in Section 4.3. Standard errors are two-way clustered around time and bond. ${ }^{* * *}$ and

** denote statistical significance at the $1 \%, 5 \%$ and $10 \%$ levels, respectively.

\section{Robustness}

\subsection{Placebo Test}

In this section, we aim to show that our results are not driven by different trends of non-CCP and CCP trading activity that are unrelated to the introduction of the Basel III leverage rule. ${ }^{19}$ Figure 6 plots the time series of the traded euro volume and shows that the two groups closely co-moved until the Basel III leverage rule was implemented, only diverging afterwards (CCP trading activity increased, while non-CCP trading activity slightly decreased).

To further explore whether the parallel trends assumption holds, we estimated placebo regressions in the spirit of Bertrand et al. (2004). In these regressions, we added bond and time fixed effects as well as control variables to obtain a more complete picture for the bond level (as opposed to a very aggregate picture in the graphs) and also mitigate selection issues. We focused on the first year of the sample period and examined the difference-in-difference around a placebo event in the middle of this year by estimating the following regression:

$$
Y_{i, t}=\alpha_{i}+\alpha_{t}+\delta\left(\text { LCCPS }_{i} \times \text { PlaceboPost }_{t}\right)+\Gamma^{\prime} W_{i, t}+u_{i, t}
$$

where $Y_{i, t}$ is either the euro volume traded, the number of bonds traded or the bid-ask spread, and PlaceboPost is a dummy that takes a value of 1 after the placebo events and 0 before.

The results reported in Table 9 are consistent with the impressions from the graph that the two groups did not develop differently during this time period. The estimated difference-in-difference coefficients are not significant at any conventional significance level ( $t$-stats range from -0.14 to 0.19 ) and are also small in terms of economic magnitude (the size of the coefficients is reduced by approximately $90 \%$ compared to Tables 5-8). 


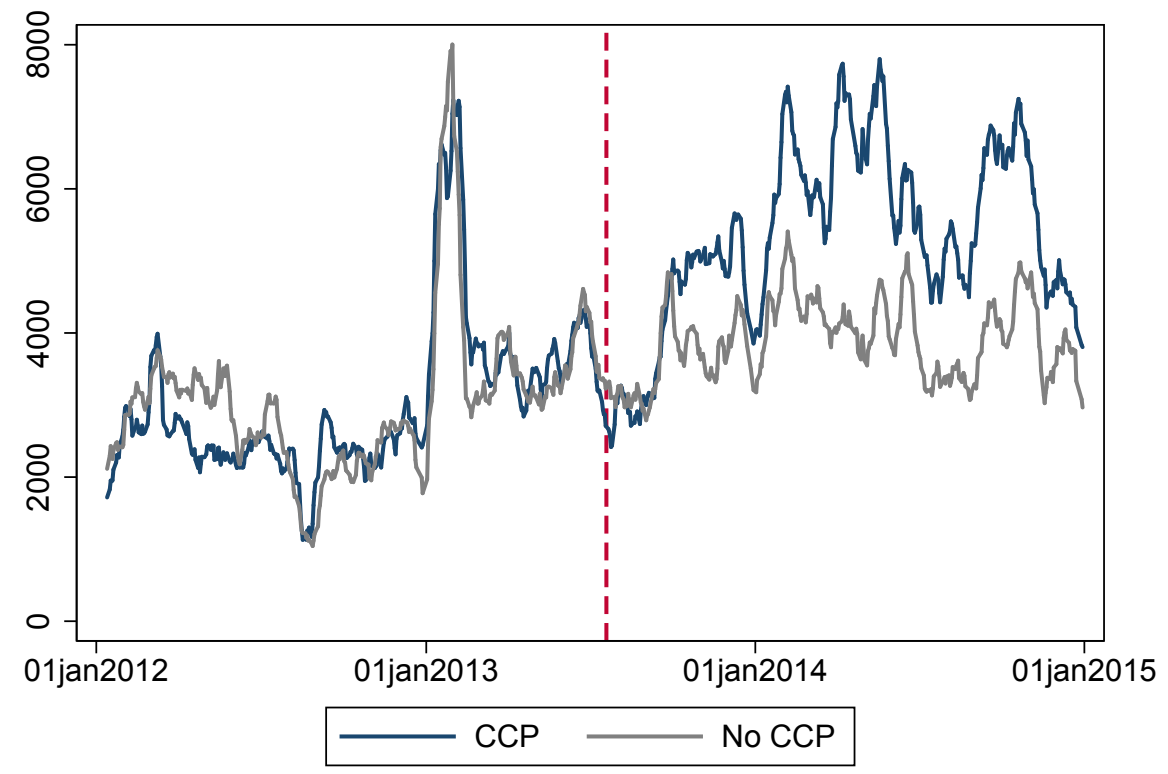

Figure 6. Parallel trends of CCP and non-CCP volume. The figure shows the euro volume between 1 January 2012 and 31 December 2014. The euro volume is a 10-day moving average aggregated over the entire sample (including Spain, Portugal, Greece and France) on a daily basis for the CCP group (blue line) and the non-CCP group (gray line). The euro volume is expressed in millions of euros.

Table 9. Placebo test.

\begin{tabular}{|c|c|c|c|}
\hline & VOL & NOB & BAS \\
\hline PlaceboPost $\times$ NoCCP & $\begin{array}{l}-0.245 \\
(-0.14)\end{array}$ & $\begin{array}{l}0.339 \\
(0.19)\end{array}$ & $\begin{array}{l}-0.000 \\
(-0.05)\end{array}$ \\
\hline sd & $\begin{array}{l}0.944^{* *} \\
(2.43)\end{array}$ & $\begin{array}{c}0.881 * * \\
(2.40)\end{array}$ & $\begin{array}{l}1.301^{* * *} \\
(6.92)\end{array}$ \\
\hline Return & $\begin{array}{l}-0.258 \\
(-0.83)\end{array}$ & $\begin{array}{l}-0.163 \\
(-0.52)\end{array}$ & $\begin{array}{l}0.057 * * * \\
(4.61)\end{array}$ \\
\hline Mid-Price & $\begin{array}{l}0.003^{* * *} \\
(2.87)\end{array}$ & $\begin{array}{l}0.002 \\
(1.46)\end{array}$ & $\begin{array}{l}-0.001^{* * *} \\
(-6.41)\end{array}$ \\
\hline Order Status & $\begin{array}{c}0.110^{* * *} \\
(10.34)\end{array}$ & $\begin{array}{l}0.109^{* * *} \\
(10.31)\end{array}$ & \\
\hline$\%$ Market Taker & $\begin{array}{l}-0.002 \\
(-0.21)\end{array}$ & $\begin{array}{l}-0.003 \\
(-0.34)\end{array}$ & \\
\hline$\%$ EBM & $\begin{array}{l}-0.002 \\
(-0.20)\end{array}$ & $\begin{array}{l}0.001 \\
(0.10)\end{array}$ & $\begin{array}{l}-0.001 \\
(-1.41)\end{array}$ \\
\hline$\%$ Buys & $\begin{array}{l}-2.631^{* * *} \\
(-5.73)\end{array}$ & $\begin{array}{l}-2.552^{* * *} \\
(-5.57)\end{array}$ & \\
\hline Trade Size & $\begin{array}{c}3.377^{* * * *} \\
(18.03)\end{array}$ & $\begin{array}{l}3.308^{* * * *} \\
(17.77)\end{array}$ & \\
\hline $\mathrm{N}$ & 32,076 & 32,076 & 68,427 \\
\hline$R^{2}$ & 0.243 & 0.249 & 0.710 \\
\hline $\begin{array}{l}\text { Bond FE } \\
\text { Time FE } \\
\text { Cluster }\end{array}$ & $\begin{array}{l}\text { Yes } \\
\text { Yes } \\
\text { Bond }\end{array}$ & $\begin{array}{l}\text { Yes } \\
\text { Yes } \\
\text { Bond }\end{array}$ & $\begin{array}{l}\text { Yes } \\
\text { Yes } \\
\text { Bond }\end{array}$ \\
\hline
\end{tabular}

This table contains point estimates of the coefficients as well as $t$-statistics (in parentheses) from estimating the following regression: $Y_{i, t}=\alpha_{i}+\alpha_{t}+\beta\left(\right.$ NoCCP $_{i} \times$ PlaceboPost $\left.t_{t}\right)+\Gamma W_{i, t}+u_{i, t}$. This analysis was conducted at the day-bond level. The sample covers the period between 1 January 2012 and 1 January 2013. The dependent variable is either the relative bid-ask spread $(B A S)$, the euro volume $(V O L)$ or the number of bonds $(N O B)$. The quotes/bonds are assigned to the treated group if the share of CCP trades for a bond is above the median for all bonds in a particular country in the BAS regression or based on the trade-level CCP usage for the NOB and VOL regression. Based on this categorization, we created the variable Treat, which takes a value of 1 for the treated group and 0 for the control group. The variable Post takes a value of 1 after 1 July 2012 and 0 before. The matrix $\Gamma$ contains the control variables described in Section 4.3. Standard errors are clustered around bond. *** and ** and denote statistical significance at the $1 \%, 5 \%$ and $10 \%$ levels, respectively. 


\subsection{Zero-Trading Days}

In the previous analyses, we only used bond group observations with non-zero trading activity to estimate Equation (3) in Section 5.1. However, our results are not sensitive to these restrictions. We re-estimated model (3) with the inclusion of trading days with zero trading activity. This has the advantage of providing a balanced sample between the two groups (corresponds to a matched sample) and not ignoring the information contained in zero-volume days. However, the disadvantage of this setting is that we cannot add trade-level control variables. Based on this sample, we estimated linear panel models as well as Tobit models. The estimated coefficients are collected in Table 10.

Table 10. Inclusion of zero-trading days.

\begin{tabular}{|c|c|c|c|c|c|c|}
\hline & \multicolumn{2}{|c|}{ Linear Model } & \multicolumn{4}{|c|}{ Tobit } \\
\hline & VOL & $N O B$ & $V O L$ & $N O B$ & $V O L$ & $N O B$ \\
\hline NoCCP & & & $\begin{array}{c}-1.852^{* * *} \\
(-4.80)\end{array}$ & $\begin{array}{c}-1.834^{* * *} \\
(-4.87)\end{array}$ & & \\
\hline Post & & & $\begin{array}{l}1.649^{* * *} \\
(5.03)\end{array}$ & $\begin{array}{c}1.565^{* * * *} \\
(4.89)\end{array}$ & & \\
\hline NoCCP $\times$ Post & $\begin{array}{c}-0.219 * * * \\
(-3.46)\end{array}$ & $\begin{array}{c}-0.171^{* * *} \\
(-2.86)\end{array}$ & $\begin{array}{c}-1.065^{* * *} \\
(-3.00)\end{array}$ & $\begin{array}{c}-0.993^{* * *} \\
(-2.85)\end{array}$ & $\begin{array}{c}-2.514^{* * *} \\
(-5.62)\end{array}$ & $\begin{array}{l}-2.432 * * * \\
(-5.61)\end{array}$ \\
\hline sd & $\begin{array}{l}0.012^{* * *} \\
(2.70)\end{array}$ & $\begin{array}{c}0.011^{* * *} \\
(2.68)\end{array}$ & $\begin{array}{c}-1.166^{* * * *} \\
(-4.77)\end{array}$ & $\begin{array}{c}-1.167^{* * *} \\
(-4.81)\end{array}$ & $\begin{array}{c}0.060 * \\
(1.82)\end{array}$ & $\begin{array}{l}0.052 \\
(1.60)\end{array}$ \\
\hline Return & $\begin{array}{l}0.407 \\
(0.45)\end{array}$ & $\begin{array}{l}0.677 \\
(0.77)\end{array}$ & $\begin{array}{l}-3.205 \\
(-0.75)\end{array}$ & $\begin{array}{l}-2.931 \\
(-0.70)\end{array}$ & $\begin{array}{l}-7.149 * * \\
(-1.98)\end{array}$ & $\begin{array}{l}-6.089 * \\
(-1.74)\end{array}$ \\
\hline Mid-Price & $\begin{array}{l}-0.004 \\
(-0.93)\end{array}$ & $\begin{array}{l}-0.008 \\
(-1.67)\end{array}$ & $\begin{array}{l}-0.028 \\
(-1.47)\end{array}$ & $\begin{array}{l}-0.032 \\
(-1.71)\end{array}$ & $\begin{array}{c}0.077^{* * *} \\
(4.85)\end{array}$ & $\begin{array}{c}0.065^{* * *} \\
(4.23)\end{array}$ \\
\hline $\mathrm{N}$ & 428,318 & 428,318 & 428,318 & 428,318 & 428,318 & 428,318 \\
\hline Bond FE & No & Yes & No & No & Yes & Yes \\
\hline Time FE & No & No & No & No & Yes & Yes \\
\hline Bond $\times$ Treat FE & Yes & Yes & No & No & No & No \\
\hline Country $\times$ Time & Yes & Yes & No & No & No & No \\
\hline Cluster & TW & TW & Bond & Bond & Bond & Bond \\
\hline
\end{tabular}

This table contains point estimates of the coefficients as well as $t$-statistics (in parentheses) from estimating the following regression: $Y_{i, t}=\alpha_{i}+\alpha_{t}+\beta\left(N o C C P_{i} \times\right.$ Post $\left._{t}\right)+\Gamma W_{i, t}+u_{i, t}$. We estimated this equation using both a linear panel model and a Tobit model. This analysis was conducted at the day-bond treatment level. The sample covers the period between 1 January 2012 and 31 December 2014 and is amended with zero-trading days. The dependent variable is either the euro volume $(V O L)$ or the number of bonds $(N O B)$. The trades are assigned to the treated group if the trade was not routed via a CCP. The variable Post takes a value of 1 after 26 June 2013 and 0 before. The matrix $\Gamma$ contains the control variables described in Section 4.3. Standard errors are clustered around bond for the Tobit regressions and two-way clustered around bond and time for the fixed-effects regression. ${ }^{* * *}, * *$ and * denote statistical significance at the $1 \%, 5 \%$ and $10 \%$ levels, respectively.

Columns (1) and (2) show the results for the linear panel model. Compared to the results in Table 5, the economic magnitude of the estimated coefficients remains fairly stable, while the statistical significance notably increases as a result of an increase in power due to a larger sample size (the number of observations in this setting increased to 428,318 , compared to only from 114,958 in the previous setting).

As noted by Tobin (1958), a linear model is not suitable for data that are censored (in this case, volume can be viewed as censored at zero), and thus, he proposed the Tobit model to account for the nonlinearity arising from a sizable number of observations at zero. Columns (3)-(6) contain the results of the Tobit model. We estimated the Tobit model without fixed effects to avoid inconsistent estimates due to the incidental parameter problem (Neyman and Scott (1948)). We also estimated a version of the model with bond and time fixed effects, where we have many observations per fixed effect, which reduces the inconsistency arising from the incidental parameter problem (see Heckman (1981) for details).

In this Tobit specification, the beta coefficients can be directly interpreted as marginal effects for the latent variable (Greene (2012)).The sign of the coefficient confirms that the trading activity developed less favorably in the non-CCP segment after the implementation of Basel III. 


\subsection{Window Dressing}

In the previous analyses, we assumed that banks changed their business models by focusing on trading activity that can be handled with the involvement of CCPs in response to the leverage rule. This is consistent with survey responses in Committee on the Global Financial System (2016). However, banks may implement window dressing to circumvent the adverse effects of the leverage rule on their business without focusing on CCP usage. Allen and Saunders (1992) and Anbiland and Senyuz (2018) found evidence that banks engage in window dressing. This means that banks avoid entering into trades around the quarter-end and thus reduce balance sheet exposures arising from trading.

Besides banks, institutional investors may engage in window dressing as well. Lakonishok et al. (1991) maintained that towards the quarter-end, investors buy securities that performed well in the past because they want to report winning securities as fund holdings in their annual reports and thus appear to be good market timers. Additionally, there is evidence of abnormally high institutional purchasing of securities that investors already hold (portfolio pumping) to inflate prices (Carhart et al. (2002); Hu et al. (2014)).

Before the introduction of the leverage rule, the window dressing attempts of institutional investors would have led to increased trading activity at the end of a quarter. Consistent with this, Table 11 indicates that the euro trading volume at the end of the quarter was on average 1.8 million higher than on a normal day. Since the introduction of the Basel III leverage rule, banks have become reluctant to be involved in trades around quarter-ends to protect balance sheet space, especially when they do not use a CCP. In line with this, we find that abnormally high trading activity diminished in the time period after the Basel III leverage rule was implemented.

At the same time, we observe that bid-ask spreads are higher $(0.048 \%)$ at the quarterend, mirroring the increased demand for intermediation services. After the implementation of the Basel III leverage rule, the transaction costs at quarter-end increased even further $(0.089 \%)$, which we interpret as evidence for additional costs imposed on banks by the leverage regulation. To study the differential impact of window dressing on quarter-ends for the CCP and non-CCP groups before and after the implementation of the Basel III leverage rule, we used a triple difference framework. We estimated the following regression:

$$
\begin{aligned}
Y_{i, t} & =\alpha_{i}+\beta_{1} \text { NoCCP }_{i}+\beta_{2} \text { Post }_{t}+\beta_{3} Q E_{t}+\beta_{4} \text { NoCCP }_{i} \times \text { Post }_{t} \\
& +\beta_{5} \text { NoCCP }_{i} \times Q E_{t}+\beta_{6} \text { Post }_{t} \times Q E_{t}+\beta_{7} \text { Post }_{t} \times Q E_{t} \times N_{o C C P}+u_{i, t}
\end{aligned}
$$

where $Y_{i, t}$ is either the euro volume traded, the number of bonds traded or the bid-ask spread, and QE is a dummy that takes a value of 1 on the last two days of a quarter (settlement in this market usually takes two days) and 0 otherwise. The results show that, as expected, the bid-ask spreads at the quarter-end increase by 0.126 percentage points more for bonds that are classified in the trading group with a low likelihood of involving a CCP compared to bonds with a higher likelihood of being traded via CCPs. This increase is statistically significant at the $5 \%$ level. Similarly, we find that trading activity decreases more in the NoCCP group, but the difference is not statistically significant. ${ }^{20}$

Overall, the results in this subsection confirm that banks engage in window dressing to comply with the leverage rule (reduce trading positions and thus balance sheet encumbrance at the end of the quarter). However, the differences between the $\mathrm{CCP}$ and non-CCP groups are not only visible at quarter-ends. This is reflected in the value of $\beta_{4}$ associated with $N o C C P \times$ Post, which is still significantly different from zero. Consistent with the evidence presented in the previous sections, this suggests that the reduction in trading activity is a more general phenomenon, such as a change in the business model of banks. 
Table 11. Window dressing at the quarter-end and Basel III.

\begin{tabular}{|c|c|c|c|}
\hline \multicolumn{4}{|c|}{ Panel A: Window Dressing at the Quarter-End before and after Basel III } \\
\hline VOL & $\begin{array}{l}-0.054 \\
(-0.94)\end{array}$ & $\begin{array}{l}0.180^{*} \\
(1.83)\end{array}$ & $-0.235^{* *}$ \\
\hline NOB & -0.046 & $0.199 * *$ & $-0.245 * *$ \\
\hline BAS & $\begin{array}{c}0.089^{* * *} \\
(4.17)\end{array}$ & $\begin{array}{c}0.048^{* * *} \\
(3.21)\end{array}$ & $\begin{array}{l}0.042 \\
(1.61)\end{array}$ \\
\hline \multicolumn{3}{|c|}{ Panel B: Difference-in-Difference-in-Difference } & BAS \\
\hline Quarter-End & $\begin{array}{l}0.069 \\
(0.53)\end{array}$ & $\begin{array}{l}-0.081 \\
(-0.64)\end{array}$ & $\begin{array}{l}0.084^{* * *} \\
(3.72)\end{array}$ \\
\hline NoCCP & $\begin{array}{l}-0.391 * * * \\
(-4.45)\end{array}$ & $\begin{array}{l}-0.401 * * * * \\
(-4.64)\end{array}$ & $\begin{array}{c}-0.332^{* * *} \\
(-6.01)\end{array}$ \\
\hline Post & $\begin{array}{l}0.743^{* * *} \\
(7.42)\end{array}$ & $\begin{array}{c}0.369^{* * *} \\
(4.65)\end{array}$ & $\begin{array}{l}-0.402 * * * \\
(-11.25)\end{array}$ \\
\hline Quarter-End $\times$ Treat & $\begin{array}{l}0.073 \\
(0.43)\end{array}$ & $\begin{array}{l}0.065 \\
(0.38)\end{array}$ & $\begin{array}{l}-0.010 \\
(-0.41)\end{array}$ \\
\hline Post $\times$ NoCCP & $\begin{array}{l}-0.703^{* * *} \\
(-5.45)\end{array}$ & $\begin{array}{l}-0.654^{* * * *} \\
(-5.17)\end{array}$ & $\begin{array}{c}0.135^{* * *} \\
(2.27)\end{array}$ \\
\hline Quarter-End $\times$ Post & $\begin{array}{l}-0.129 \\
(-0.82)\end{array}$ & $\begin{array}{l}-0.062 \\
(-0.42)\end{array}$ & $\begin{array}{c}-0.075^{* * *} \\
(-3.24)\end{array}$ \\
\hline Quarter-End $\times$ NoCCP $\times$ Post & $\begin{array}{l}-0.096 \\
(-0.51)\end{array}$ & $\begin{array}{l}-0.092 \\
(-0.49)\end{array}$ & $\begin{array}{c}0.126^{* *} \\
(2.19)\end{array}$ \\
\hline $\mathrm{N}$ & 428,318 & 428,318 & 212,058 \\
\hline$R^{2}$ & 0.079 & 0.173 & 0.334 \\
\hline
\end{tabular}

Panel A shows the difference in the EUR volume $(V O L)$, the number of bonds traded $(N O B)$ and the relative bid-ask spread $(B A S)$ between normal days and the two trading days before the quarter-end. Column 1 shows the results for the post-Basel III period (26 June 2013-31 December 2014), and column 2 lists the results for the period before its implementation (1 January 2012-26 June 2013). Column 3 shows the difference between the differences in these two periods. The $t$-statistics in parentheses were obtained by regressing the variable of interest on a Quarter-End dummy (post and pre columns) or from a difference-in-difference regression. Standard errors are clustered around bond. Panel B contains point estimates of the coefficients as well as $t$-statistics (in parentheses) from estimating the following regression: $Y_{i, t}=\alpha_{i}+\beta_{1} N_{o C C} P_{i}+\beta_{2}$ Post $_{t}+\beta_{3} Q E_{t}+\beta_{4} N_{o C C} P_{i} \times$ Post $_{t}+\beta_{5} N_{o C C C} \times Q E_{t}+\beta_{6}$ Post $_{t} \times Q E_{t}+\beta_{7}$ Post $_{t} \times Q E_{t} \times N o C C P_{i}+u_{i, t}$. This analysis was conducted at the day-bond treatment level. The sample covers the period between 1 January 2012 and 1 January 2013. The dependent variable is either the euro volume $(V O L)$, the number of bonds (NOB) or the bid-ask spread $(B A S)$ The trades are assigned to the treated group if the trade was routed via a CCP in the regressions with $V O L$ and $N O B$. In the regressions with $B A S$ as the dependent variable, quotes/bonds are assigned to the treated group if the share of CCP trades for a bond is below the median for all bonds in a particular country (LCCPU). In the regressions with $N O B$ and $V O L$, the trades are assigned to the treated group if the trade was not routed via a CCP. The variable Post takes a value of 1 after 26 June 2013 and 0 before. The matrix $\Gamma$ contains the control variables described in Section 4.3. In Panel B, standard errors are two-way clustered around bond and time. In Panels A and $\mathrm{B},{ }^{* * *},{ }^{* *}$ and ${ }^{*}$ denote statistical significance at the $1 \%, 5 \%$ and $10 \%$ levels, respectively.

\subsection{Country Groups}

As shown by the descriptive statistics reported in the beginning, the sample is primarily dominated by Italian trading activity. This is especially true for CCP trading activity due to the high share of CCP trading in Italy. In the previous analyses, we accounted for this by introducing country and bond fixed effects. While these fixed effects eliminate the possibility that our results are driven by differential development of the Italian market compared to the other countries in the sample, it does not exclude that the responses of the non-CCP and CCP groups within Italy disproportionately influence our results due to the high weight of Italian observations. In order to address this concern, we estimated Equations (1)-(3) for two country groups: Italy and Ireland (the GIIPS countries in the sample the abbreviation GIIPS refers to the euro-zone periphery countries and originates from the first letters of Greece, Ireland, Italy, Portugal and Spain) and Germany, the Netherlands, Austria and Finland (CORE countries in the sample - referring to core euro-area countries). The results are reported in Table 12.

The results show that the effect is present in both samples (CORE and GIIPS countries). The coefficients have the expected signs and are large in economic magnitude. Moreover, they are statistically significant in five out of six cases. The loss of significance for the bid-ask spread in the GIIPS sample can be attributed to a loss in power as a result of a significant decrease in the number of observations in the divided country groups. 
Table 12. Country group analysis.

\begin{tabular}{|c|c|c|c|c|c|c|}
\hline & \multicolumn{3}{|c|}{ GIIPS } & \multicolumn{3}{|c|}{ CORE } \\
\hline & $V O L$ & $N O B$ & $B A S$ & $V O L$ & $N O B$ & $B A S$ \\
\hline Post $\times$ NoCCP & $\begin{array}{c}-8.672^{* * *} \\
(-3.30)\end{array}$ & $\begin{array}{c}-6.739 * * * \\
(-2.63)\end{array}$ & $\begin{array}{l}0.001 \\
(0.92)\end{array}$ & $\begin{array}{l}-1.770 * * \\
(-1.96)\end{array}$ & $\begin{array}{l}-1.630 * * \\
(-1.96)\end{array}$ & $\begin{array}{l}0.003^{* * *} \\
(2.81)\end{array}$ \\
\hline sd & $\begin{array}{c}3.247^{* * *} \\
(3.72)\end{array}$ & $\begin{array}{c}3.040^{* * *} \\
(3.61)\end{array}$ & $\begin{array}{l}0.812^{* * *} \\
(5.54)\end{array}$ & $\begin{array}{c}1.373^{*} \\
(1.75)\end{array}$ & $\begin{array}{c}1.262 * \\
(1.77)\end{array}$ & $\begin{array}{c}2.217^{* * *} \\
(3.69)\end{array}$ \\
\hline Return & $\begin{array}{l}-0.706 \\
(-0.96)\end{array}$ & $\begin{array}{l}-0.530 \\
(-0.74)\end{array}$ & $\begin{array}{l}0.206^{* *} \\
(2.02)\end{array}$ & $\begin{array}{l}0.034 \\
(0.09)\end{array}$ & $\begin{array}{l}0.159 \\
(0.44)\end{array}$ & $\begin{array}{c}0.267^{*} \\
(1.84)\end{array}$ \\
\hline Mid-Price & 0.001 & -0.001 & $-0.000^{* * *}$ & 0.001 & 0.000 & $-0.000 * *$ \\
\hline$\%$ EBM & $\begin{array}{c}(0.45) \\
-0.077^{* * *} \\
(-8.72)\end{array}$ & $\begin{array}{c}(-0.66) \\
-0.073^{* * *} \\
(-8.65)\end{array}$ & $\begin{array}{l}(-6.36) \\
-0.000 \\
(-0.33)\end{array}$ & $\begin{array}{c}(1.31) \\
-0.004 \\
(-1.13)\end{array}$ & $\begin{array}{c}(0.00) \\
-0.003 \\
(-0.94)\end{array}$ & $\begin{array}{l}(-2.13) \\
-0.000 \\
(-1.01)\end{array}$ \\
\hline $\mathrm{N}$ & 55,120 & 55,120 & 68,622 & 36,675 & 36,675 & 101,822 \\
\hline$R^{2}$ & 0.307 & 0.311 & 0.882 & 0.301 & 0.311 & 0.363 \\
\hline Bond $\times$ Treat FE & YES & YES & YES & YES & YES & YES \\
\hline Country $\times$ Time FE & YES & YES & YES & YES & YES & YES \\
\hline Cluster & TW & TW & TW & TW & TW & TW \\
\hline
\end{tabular}

Panel A of this table contains point estimates of the coefficients as well as $t$-statistics (in parentheses) from estimating the following regression: $Y_{i, t}=\alpha_{i}+\alpha_{t}+\beta\left(\right.$ Treat $_{i} \times$ Post $\left._{t}\right)+\Gamma W_{i, t}+u_{i, t}$. We ran these regressions separately for the GIIPS (Italy and Ireland) and CORE countries (Austria, Germany and The Netherlands) in our sample. This analysis was conducted at the day-bond-group level. The sample covers the period between 1 January 2012 and 31 December 2014. The dependent variable is either the euro volume (VOL), the number of bonds $(N O B)$ or the bid-ask spread $(B A S)$. The trades are assigned to the treated group if the trade was not routed via a CCP in the regressions with $V O L$ and $N O B$. In the regressions with $B A S$ as a dependent variable, quotes/bonds are assigned to the treated group if the share of CCP trades for a bond is below the median for all bonds in a particular country (LCCPU). The variable Post takes a value of 1 after 26 June 2013 and 0 before. The matrix $\Gamma$ contains the control variables described in Section 4.3. Standard errors are two-way clustered around both bond and time. ${ }^{* *},{ }^{* *}$ and * denote statistical significance at the $1 \%, 5 \%$ and $10 \%$ levels, respectively.

\section{Conclusions, Limitations and Outlook}

This paper reveals a strong increase in CCP usage in the European sovereign bond cash market as a response to the introduction of the Basel III leverage rule, which is driven by the need of market makers to economize balance sheet usage. Our results suggest that the leverage rule impairs liquidity provision by banks acting as market makers. We infer this from a comparison of the development of trading activity in two groups: (1) trades that were executed without the interposition of a CCP (more affected by the leverage rule) and (2) trades that were routed via CCPs. Consistent with a detrimental impact of the leverage rule on liquidity provision, we find that trading activity in the non-CCP group decreased to a significantly greater extent in response.

These results highlight the importance of balance sheet effects arising from the netting benefits of CCPs, which have not received much attention due to the focus on derivative and repo markets in previous research in this field. The MTS sovereign bond cash market constitutes an ideal setting to study balance sheet effects because counterparty risk plays a minimal role (almost eliminated by the settlement mechanism). Thus, our results also help to explain the popularity of CCPs in cash markets.

In a broader context, this paper confirms the argument made by Duffie (2017) that the introduction of the leverage rule impairs safe but less profitable activities that require a lot of balance sheet space. Moreover, our results indicate that banks make use of regulatory arbitrage by using CCPs to bear balance sheet positions that are costly for regulated financial institutions. This should concern regulators because departure from the riskbased capital framework might lead to unanticipated effects. More research is required to better understand the trade-off between safety and the intermediation capacity of banks.

However, this paper faces a few limitations, mostly due to the unavailbility of data. As mentioned before, ideally we would observe the identity of the dealers. This would allow for the inclusion of dealer fixed effects and therfore a better identifcation in the regressions. Moreover, the research in this paper could be extended along several lines. It would be interesting to investigate CCP usage around other regulatory events. Recently, the Supplementary Leverage Ratio in the US was subject to a temporary change with the aim to remove pressure from the US Treaury market and to increase the lending capacity of banks (Fleming and Keane (2021)). It would be an interesting avenue for future research 
to study the CCP usage around this event. Moreover, the MTS data set has become more comprehensive recently and contains additional liquidity measures. It would be interesting to see how regulation and CCP usage impact these liquidity measures.

Funding: Stiftung für Wissenschaftliche Forschung University of Zurich.

Institutional Review Board Statement: Not applicable.

Informed Consent Statement: Not applicable.

Data Availability Statement: Proprietary data from MTS. Data can be purchased from this source.

Conflicts of Interest: The author declares no conflict of interest.

\section{Notes}

1 The regulation set a target leverage ratio of 3\% for a trial period between 2013 and 2017. This target ratio was not immediately a binding minimum capital requirement (Pillar 1). However, it was immediately part of the supervisory review of banks (Pillar 2) and disclosure requirements (Pillar 3). Moreover, the leverage ratio became a binding capital requirement (Pillar 1 ) in 2018 (PWC (2018)). As can be seen from Figure 1, the adoption of the rule into law and the anticipation that it would become a part of Pillar 1 led to a significant decrease in bank leverage. This is consistent with Committee on the Global Financial System (2016), whose survey results revealed that banks were already estimating current regulatory costs according to fully phased-in Basel III, which indicates that the adjustment of business models had already taken place.

2 See Section 2.3 and Table 1 for more details on the settlement infrastructure of the MTS platform.

3 CCPs have become increasingly important in cash markets. In 2015, bond trades worth more than 66 trillion were routed via the three largest CCPs in Europe. (The ECB names LCH.Clearnet SA, LCH.Clearnet Ltd. and EUREX Clearing AG as the biggest CCPs according to the number of participants.) On MTS, more than $60 \%$ of the trades were executed via CCPs. BCBS (2014), p. 2 paragraph 12 says: "The exposure measure for the leverage ratio should generally follow the accounting value". The Basel Committee published its new Basel III rule book (BCBS (2010)) on 16 December 2010.

The 2013 document was termed: "Consultative Document Revised Basel III leverage ratio framework and disclosure requirements". Due to interoperability arrangements, dealers in the Italian market can either be a CC\&G or LCH.Clearnet SA member because the two institutions form a single virtual CCP (each CCP is a member of the other CCP). For further information, consult: https:/ / www.bancaditalia.it/compiti/sispaga-mercati/controparte-centrale (accessed on 1 September 2017).

8 Further information on membership eligibility can be found at: https:/ / www.lch.com/membership (accessed on 1 November 2017).

9 The MTS Cash Domestic Market Rules (MTS (2017)) specify on p. 22: “If Quotes and Orders matching on the Market, are submitted by two Dealers using the CCP Services on a Financial Instrument eligible for CCP Service, the execution of the Trade shall be automatic subject to the registration of the Trade by the CCP, if the applicable CCP regulations provide that the novation of the relevant Trade shall take place upon the registration of the Trade by the CCP".

10 According to the LCH Limited Procedures section 2B RepoClear clearing service (http:/ / www.lch.com/rules-regulations/rulebooks / ltd (accessed on 1 September 2017), the netting process works as follows: (1) First, all delivery obligations are collected (for each settlement day and settlement system). (2) Next, contracts arising from (eligible) bond trades are netted by the CCP at the participant, security and settlement system levels. (3) Netting takes place every day and considers all (eligible) contracts for settlement on that day. (4) Finally, the netting process creates net delivery and receipt obligations (for securities and for cash) for each member, securities issue and settlement system combination. The procedures for the LCH SA work very similarly (see http:/ / www.lch.com/rules-regulations/rulebooks/s (accessed on 1 September 2017) and CC\&G http:/ /www.lseg.com/node/5437 (accessed on 1 September 2017).

11 LCH. Limited (2017) states that "In such netting process no distinction will be made between securities forming part of RepoClear Contracts arising from RepoClear Repo Transactions, Repo Trades or Bond Trades".

Specifically, the discussion in this section is based on the rules contained in BCBS $(2010,2013,2014)$.

Initially and during our entire sample period, the Basel III framework relied on accounting data to calculate the exposure arising from trade liabilities and receivables. However, in a finalized version of the Basel III framework (BCBS (2017b)), the BCBS recognized that different accounting standards (e.g., US Gaap and IFRS) and choices (settlement vs. trade date accounting) lead to different impacts of trading activity on the exposure measure. Thus, Basel III rules define a deviation from accounting standards for the purpose of calculating the exposure arising from trade payables and receivables. These rules specify that even if banks are allowed to net trade payables and receivables under their respective accounting standards, they are not allowed to do so for the purpose of calculating the Basel III leverage ratio. However, the regulation defines its own criteria for circumstances under which banks are allowed to net exposures. Note that these changes were not announced during our sample period. Their possibility was first mentioned in a consultative paper issued in 2016 (BCBS (2016)). 
14 The receivables and liabilities remain in the balance sheet until the trade is settled. Currently, on MTS, the settlement date is T + 2 days from the trade date $\mathrm{T}$ (date on which the involved parties agree to exchange the bonds).

15 According to IAS 39 AG53, the chosen method has to be "applied consistently for all purchases and sales of financial assets that belong to the same category of financial assets". Settlement date accounting seems to be the preferable method in the context of balance sheet exposures arising from unsettled trades described above but can be inferior to trade date accounting when it comes to hedging instruments (position appears in the balance sheet later) and non-regular way transactions (IAS 39 AG12), e.g., long settlement transactions (transaction has to be accounted as the derivative between the trade and settlement date).

16 A comprehensive explanation of the applied screens and error corrections can be found in Östberg and Richter (2017).

17 The distribution of bonds across countries is as follows: Austria 24, Belgium 191, Germany 157, Finland 18, Ireland 31 , Italy 192 and The Netherlands 71.

18 The bond and trade characteristics that are associated with CCP usage and the way that market makers can use these variables to predict the likelihood of a CCP counterparty are discussed in detail in Section 5.2.

19 If the two groups exhibit diverging trends, the difference-in-difference coefficient may just capture this instead of differences between the two groups arising from the introduction of the Basel III leverage rule.

20 The rather weak results for the trading activity measures seem to be caused by unequally developed repo trading in different national MTS markets. As reported by Sigelman and Zeng (2000), banks significantly reduce repo trading at quarter-ends. Italy is the only market that has a big MTS repo market. Many cash trades are associated with repo trades (Duffie (1996)). Italy also has a high share of CCP trades. Thus, the reduction in repo trading might have more pronounced effects on the CCP trading activity and might act as a counterfactual. In an unreported analysis, we verified that the $\beta_{7}$ coefficient becomes significant in the $V O L$ and $N O B$ regressions when Italy is excluded.

\section{References}

Adrian, Tobias, Nina Boyarchenko, and Or Shachar. 2017. Dealer balance sheets and bond liquidity provision. Journal of Monetary Economics 89: 92-109. [CrossRef]

Allen, Linda, and Anthony Saunders. 1992. Bank window dressing: Theory and evidence. Journal of Banking E Finance 16: 585-623.

Anbil, Sriya, and Zeynep Senyuz. 2018. The Regulatory and Monetary Policy Nexus in the Repo Market. Available online: https: / / ssrn.com/abstract=3187697 (accessed on 3 December 2021).

American Institute of Certified Public Accountants. 2017. Accounting Guide: Brokers and Dealers in Securities. Hoboken: John Wiley \& Sons.

Bank for International Settlements. 1992. Delivery versus Payment in Security Settlement Systems. Available online: http:/ /www.bis. org/cpmi/publ/d06.pdf (accessed on 3 December 2021).

Bao, Jack, Maureen O'Hara, and Xing Alex Zhou. 2016. The Volcker Rule and Market-Making in Times of Stress. Journal of Financial Economics, Forthcoming, Fourth Annual Conference on Financial Market Regulation. Available online: https://ssrn.com/ abstract $=2836714$ (accessed on 3 December 2021)

Basel Committee on Banking Supervision. 2017a. Basel III Monitoring Report. Available online: http://www.bis.org/bcbs/publ/d397 .pdf (accessed on 3 December 2021).

Basel Committee on Banking Supervision. 2017b. Basel III: Finalising Post-Crisis Reforms. Available online: https:/ /www.bis.org/ bcbs / publ/d424.htm (accessed on 3 December 2021).

Basel Committee on Banking Supervision. 2010. Basel III: A Global Regulatory Framework for More Resilient Banks and Banking Systems. Available online: https://www.bis.org/publ/bcbs189.pdf (accessed on 3 December 2021).

Basel Committee on Banking Supervision. 2013. Revised Basel III Leverage Ratio Framework and Disclosure RequirementsConsultative Document. Available online: https:/ /www.bis.org/publ/bcbs251.pdf (accessed on 3 December 2021).

Basel Committee on Banking Supervision. 2014. Basel III Leverage Ratio Framework and Disclosure Requirements. Available online: http:/ / www.bis.org/publ/bcbs270.pdf (accessed on 3 December 2021).

Basel Committee on Banking Supervision. 2016. Revisions to the Basel III Leverage Ratio Framework-Consultative Document. Available online: https:/ / www.bis.org/bcbs/publ/d365.htm (accessed on on 3 December 2021).

Bellia, Mario, Roberto Panzica, Giulio Girardi, Loriana Pelizzon, and Tuomas A. Peltonen. 2018. The Demand for Central Clearing: To Clear or Not to Clear, That Is the Question. SAFE Working Paper No. 193. Frankfurt: Leibniz Institute for Financial Research SAFE.

Bertrand, Marianne, Esther Duflo, and Sendhil Mullainathan. 2004. How much should we trust differences-in-differences estimates? The Quarterly Journal of Economics 119: 249-75.

Bessembinder, Hendrik, Stacey E. Jacobsen, William Maxwell, and Kumar Venkataraman. 2018. Capital commitment and illiquidity in corporate bonds. Journal of Finance 73: 1615-61.

Blum, Jürg M. 2008. Why Basel II may need a leverage ratio restriction. Journal of Banking \& Finance 32: 1699-707.

Boissel, Charles, Francois Derrien, Evren Ors, and David Thesmar. 2017. Systemic risk in clearing houses: Evidence from the European repo market. Journal of Financial Economics 125: 511-36. [CrossRef]

Brunnermeier, Markus K. 2009. Deciphering the liquidity and credit crunch 2007-2008. The Journal of Economic Perspectives 23: 77-100. [CrossRef] 
Carhart, Mark M., Ron Kaniel, David K. Musto, and Adam V. Reed. 2002. Leaning for the tape: Evidence of gaming behavior in equity mutual funds. Journal of Finance 57: 661-93. [CrossRef]

Comerton-Forde, Carole, Terrence Hendershott, Charles M. Jones, Pamela C. Moulton, and Mark S. Seasholes. 2010. Time Variation in Liquidity: The Role of Market Maker Inventories and Revenues. The Journal of Finance 65: 295-331.

Committee on Payments and Market Infrastructures. 2015. Statistics on Payment, Clearing and Settlement Systems in the CPMI Countries-Figures for 2015. Available online: http:/ / www.bis.org/cpmi/publ/d155.htm (accessed on 3 December 2021).

Committee on the Global Financial System. 2016. Fixed Income Market Liquidity. CGFS Papers No. 55. Basel: Bank for IInternational Settlements.

Cont, Rama, and Thomas Kokholm. 2014. Central clearing of OTC derivatives: Bilateral vs. multilateral netting. Statistics $\mathcal{E}$ Risk Modeling 131: 3-22.

Di Maggio, Marco. 2017. Comment on: Dealer Balance Sheets and Bond Liquidity Provision by Adrian, Boyarchenko and Shachar. Journal of Monetary Economics 89: 110-12. [CrossRef]

Dunne, Peter G., Harald Hau, and M. Moore. 2010. A Tale of Two Platforms: Dealer Intermediation in the European Sovereign Bond Market. INSEAD Working Paper No. 2010/64/FIN. Paris: INSEAD.

Duffie, Darrell. 2020. Still the World's Safe Haven? Redesigning the US Treasury market after the COVID-19 crisis'. Hutchins Center on Fiscal and Monetary Policy at Brookings. Available online: https:/ / www.brookings.edu/research/still-the-worlds-safe-haven (accessed on 28 November 2021).

Duffie, Darrell. 1996. Special repo rates. The Journal of Finance 51: 493-526. [CrossRef]

Duffie, Darrell. 2017. Financial regulatory reform after the crisis: An assessment. Mangement Science 64: 4835-57. [CrossRef]

Dufour, Alfonso, Miriam Marra, and Ivan Sangiorgi. 2019. Determinants of intraday dynamics and collateral selection in centrally cleared and bilateral repos. Journal of Banking and Finance 107: 1-26.

Fleming, Michael J., and Frank M. Keane. 2021. The Netting Efficiencies of Marketwide Central Clearing. FRB of New York Staff Report No. 964. New York: Federal Reserve Bank of New York.

Foucault, Thierry, Pagano Marco, and Alisa Röell. 2013. Market Liquidity: Theory, Evidence, and Policy. Oxford: Oxford University Press. Greene, William H. 2012. Econometric Analysis, 7th ed. London: Pearson Education.

Haene, Philipp, and Andy Sturm. 2009. Optimal Central Counterparty Risk Management. Working Papers No. 2009-07. Bern: Swiss National Bank.

Heckman, James J. 1981. The Incidental Parameters Problem and the Problem of Initial Conditions in Estimating a Discrete TimeDiscrete Data Stochastic Process. Strutural Analysis of Discrete Data, S. pp. 179-95.

Ho, Thomas, and Hans R. Stoll. 1981. Optimal dealer pricing under transactions and return uncertainty. Journal of Financial Economics 9: 47-73.

Hu, Gang, David R. McLean, Jeffrey Pontiff, and Qinghai Wang. 2014. The year-end trading activities of institutional investors: Evidence from daily trades. The Review of Financial Studies 27: 1593-614. [CrossRef]

Lakonishok, Josef, Andrei Shleifer, Richard Thaler, and Robert Vishny. 1991. Window dressing by pension fund managers. American Economic Review 81: 227-31.

LCH. Limited. 2017. Procedures Section 2B RepoClear Clearing Service. Available online: https://www.lch.com/system/files/media root/Section\%202B\%20-\%20RepoClear\%20Service.pdf (accessed on 20 December 2017).

Loon, Yee C., and Zhaodong K. Zhong. 2014. The impact of central clearing on counterparty risk, liquidity, and trading: Evidence from the credit default swap market. Journal of Financial Economics 112: 91-115. [CrossRef]

Mancini, Loriano, Angelo Ranaldo, and Jan Wrampelmeyer. 2015. The euro interbank repo market. The Review of Financial Studies 29: 1747-79. [CrossRef]

Mendoza, Enrique G. 2010. Sudden stops, financial crises, and leverage. The American Economic Review 100: 1941-66. [CrossRef]

Neyman, Jerzy, and Elizabeth L. Scott. 1948. Consistent estimates based on partially consistent observations. Econometrica 16: 1-32. [CrossRef]

MTS. 2017. MTS Cash Domestic Rules. Available online: https:/ /www.mtsmarkets.com/sites/default/files/content/documents/ MTS\%20Cash\%20Domestic\%20Market\%20Rules\%2014\%2012\% \202017\%20clean.pdf (accessed on 30 December 2017).

Östberg, Per, and Thomas Richter. 2017. The Sovereign Debt Crisis: Rebalancing or Freezes? Swiss Finance Institute Research Paper No. 17/32. Geneva: Swiss Finance Institute.

O'Hara, Maureen, and Xing A. Zhou. 2021. The electronic evolution of corporate bond dealers. Journal of Financial Economics 140: 368-90. [CrossRef]

PWC. 2018. Basel IV: The Leverage Ratio Revisited. Available online: https:/ / www.pwc.co.uk/financial-services/assets/pdf/hottopic-the-leverage-ratio.pdf (accessed on 1 February 2018).

Sigelman, Lee, and Langche Zeng. 2000. Analyzing Censored and Sample-Selected Data with Tobit and Heckit Models. Political Analysis 8: 167-82. [CrossRef]

Grill, Michael, Jan Hannes Lang, and Jonathan Smith. 2017. The Leverage Ratio, Risk-Taking and Bank Stability. European Central Bank Working Paper No. 2079. Frankfurt: European Central Bank.

Tobin, James. 1958. Estimation of relationships for limited dependent variables. Econometrica 26: 24-36. [CrossRef] 